\title{
The Avant-garde as Spontaneous Contagion: The Case of Bucharest ${ }^{*}$ Petre Răileanu
}

\begin{abstract}
DADA, this wind from the East, sweeps the world that is beginning to age. At the beginning of the twentieth century the first globalization, led by some

youths at odds with the times, consists of negation and the ironic exultation of Nothingness.
\end{abstract}

\section{Spontaneous Contagion. The Two Europes. The Cart and the Steam Engine. A Unified Continental Art. "Eruption of a European Spirit."}

The appearance and flourishing of the avant-garde movements in Europe are less a product of imitation than a kind of "spontaneous contagion." Before the arrival of surrealism, a French phenomenon, there were a number of avant-garde centers on the continent: Paris, with Alfred Jarry, Apollinaire, the impressionists, the Fauves, etc.; Paris, again, where Marinetti launched his "Manifeste du futurisme," but also Craiova, where Marinetti's manifesto was published in Romanian in the local paper, Democrația, the very same day-20 February 1909-as in Le Figaro; Dresden, with the group Die Brücke; Bucharest, with Tristan Tzara, Ion Vinea, and Marcel Iancu/Janco gathered around the magazine Simbolul (Symbol) in 1912, and with texts by Urmuz written before 1910 and discovered in the 1920s; Prague, with the group Osma (The Eight) of 1907 and poetism, the 1920s movement of Karel Teige. Moscow and Mikhail Larionov's 1913 rayonism; London with Ezra Pound and Wyndham Lewis's vorticism of 1914; Budapest and Vienna with the Hungarian journal Ma (Today) (1916-1925) led by Lajos Kassák; St. Petersburg with Kasimir Malevich's suprematism of 1915; Zagreb and the journal Zenit of 1925; Zurich, in 1916, with the Cabaret Voltaire and its homonymous journal and

\footnotetext{
* This article borrows, in adapted and reordered form, from multiple works published previously by the author: Ghérasim Luca (Paris: Oxus, 2004), Fundoianu/Fondane et l'avant-garde, edited in collaboration with Michel Carassou (Paris: Paris-Méditerranée, 1999); L'Avant-garde roumaine, special issue of the journal Le Rameau d'or no. 2(3) (Bucharest: Romanian Cultural Fundation, 1995); The Romanian Avant-garde (Bucharest: Plural, 1999 - an enhanced Englishlanguage version of the preceding title).
}

Dada/Surrealism No. 20 (2015) 
Dada (movement and journal), with Hugo Ball, Richard Huelsenbeck, Marcel Janco, and Tristan Tzara; Warsaw and the formist group along with the important publication, Blok; or else Barcelona, 1917, with the initial numbers of Picabia's 391; Madrid and the ultraist movement, 1918; and also Lisbon, where Pessoa, AlmadaNegreiros, and Santa Rita published the single issue of Portugal futurista (Futurist Portugal).

At the time of the avant-gardes, Europe lived in tune with its capitals. Against the background of a true "international of intellectuals" of unprecedented scale, artists and authors put forth their ideas quite freely, and at the same time they were open to the ideas of others in full reciprocity. The avant-garde movements allowed the provinces and peripheral areas to rise to the level of the capitals.

For the first time, Europe ceased to be a virtual or fictional entity and a common European reality started to take shape at least in the realm of the arts. This phenomenon is all the more worthy of note given that the end of the First World War coincided with an event that is undoubtedly one of its most important direct consequences, yet ignored by the majority of the historians of the avantgarde, namely, the dawn of several new states which were created as a result of the disintegration of the Austro-Hungarian empire: Hungary; the Kingdom of Serbs, Croats and Slovenes, which would later become Yugoslavia; Czechoslovakia; and finally post-war Romania, formed as a result of an event to which Romanian historians refer as the creation of national unity by the integration of Transylvania, as well as of two regions Bessarabia and Bucovina (the latter the birth place of Paul Celan) that were historically Romanian, yet later partially re-annexed by the Soviet Union.

It is easy to see why, for the avant-garde protagonists of Central and Eastern Europe, the stakes were much higher than for their counterparts in the West: it was a matter of catching up with history and bringing into harmony the continent's cultural contours with its geography, which had long ignored these regions. Europe, wrote in 1922 the Romanian poet B. Fundoianu who a few years later became the French-language author Benjamin Fondane, would be "o noțiune geografică devenită, printr-un act de iluzie, noțiune culturală; o entitate, injustă geograficește, ea exclude estul, adică jumătate" ("Note dintr-un sertar" 424) 'a geographical notion that has, by virtue of an illusion, become a cultural idea; geographically an unfair entity, it excludes the East, that is to say, half of the continent.' Why, then, the necessity to belong to a Europe that is a mere illusion? In effect, the early twentieth century avant-gardes filled the illusion with content and created the link that had been missing. During this period the avant-gardes made possible the emergence of a new reality: that of a geographical and cultural Europe that no longer operated with the concept of a "center" and a "periphery," because the center of the continent resided-simultaneously-in each of its capitals.

In Eastern Europe, the artistic avant-gardes manifested themselves less as a negation of tradition than as an affirmation of an identity within continental art. To 
clarify: in terms of programmatic negation and paradoxical or contrarian strategies of communication (as manifestos often addressed their readers with formulas that were rather insulting, to say the least: "Cetitor, deparazitează-ţi creierul" (Voronca, “Aviogramă") 'Reader, debug your brain'; “Domnilor imbecili, bărbieriţi-vă odată şi cu ghilotina!" ("Frigidaire”) 'Idiotic sirs, why don't you shave with the guillotine for once!', these avant-garde movements remained marginal phenomena in their countries. The rise of traditionalist and nationalist schools of thought, that gradually overtook everything, represented a challenge to the avant-gardes and pushed them to dissolution. The same was true in the Soviet Union, where avant-garde art became official art, but only for a short while and in a double strategic move of the new political powers: acquisition of intellectual legitimacy and assertion of authority over all manifestations of freedom.

In Romania, as in all the other Central and Eastern European countries, the avant-gardes would have to overcome a double series of obstacles. In addition to the moral, psychological, and aesthetic ones, present everywhere, here there were social and economic barriers, too. These societies were at the dawn of modern civilization, at the onset of industrialization and urbanization, but without having altogether left behind the mentalities and human relations characteristic of rural economies. The cart and the steam engine represented for Fernand Braudel the respective symbols of the two kinds of Europe, eastern and western, during the first decades of the twentieth century (424). The two symbolized, in the vision that the avant-gardes gave us of the eastern half of Europe, two realities condemned to coexist as in an emblem of this region.

During this period, the Romanian artists and poets engaged in the avant-garde adventure were led, by way of a voluntary assassination of sorts, to put an end to their previous lives. The break intervened primarily in the concept of artistic creation and language. However, if only for a brief period, they led an oddly double existence: in texts that deployed a nervous, elliptical syntax dominated by a lexicon of urban, machinist civilization - rubber (in the sense of "tire"), celluloid, vocal preservative, car horn, airplane, radio telegraphy, telegraph, cable, barometer, elevator, jazz, etc. - here and there traditional culture appeared, too, as in man under the shoulder-yoke, an image of the peasant selling goods in the city, but also a metaphor for man crushed by history's implacable burden. The most extreme rupture came in the act of adopting French as a language of expression and, in certain cases, taking up residence on French soil.

For those who stayed, modernity was the only possible option, with all the changes it presumed in daily life. Urbanism, industry, architecture, interior decoration, furniture design, and sports were all domains they tackled. Between 1922 and 1938 Marcel Janco built several modern buildings in Bucharest, but he was also the initiator of two projects that constituted a novelty in terms of social investment: the Institute of Climatotherapy at Predeal (in the Romanian Carpathians), the first private sanatorium in Romania wholly dedicated to pulmonary diseases, built in 1934, and the FSSR (Federation of the Romanian 
Swimmers' Association) natatorium in Bucharest, built in 1929. Marcel Janco's architectural work was in some ways akin to that of the Czechoslovak architect Jirí Kroha (1893-1974) working in Brno, the author of Sociologický fragment bydlení (Housing: A Sociological Fragment), published in 1934 on the occasion of the eponymous exhibition in Prague, in which he favored a new approach to everyday life, calling for a new lifestyle. Let us mention that, along the same lines, in Bucharest the artists surrounding the magazine Integral, 1925-1928, Victor Brauner, M.H. Maxy, and Corneliu Michăilescu were laying the foundations of a Workshop for Decorative Arts meant to produce "Decorațiuni interioare, mobile, covoare, ceramică, decoruri și costume teatrale, construcții scenice, afișe teatrale și cinematice" 'interior decorations, furniture, rugs, ceramics, theatrical costumes and stage decor, set construction, posters for the theater and cinema.. ${ }^{1}$ One year later, the same artists opened "Academia Artelor Decorative" (the Decorative Arts Academy) which also featured a "Salon Permanent de Artă Decorativă pentru Interiorul Modern" (Permanent Salon for the Modern Interior). The salon exhibited objects and pieces of furniture of their own design and making, illustrating the process from conception to execution, a whole new concept of interior decoration. These creations sometimes included traditional forms and motifs while remaining resolutely modern. The goal was to define a new aesthetic with two key components: beauty and functionality.

The artists remained in contact across borders and language differences. The Romanian avant-garde magazines Contimporanul (The Contemporary), Integral, Punct (Period), and unu 'one,' all dedicated the last pages of each number to permanent columns in which accounts were given of similar publications from all over Europe that promoted the same innovative approach. Thus a vast network of tendencies and names was created that left the impression of a planetary movement of ideas. In a note in French published in Contimporanul referring to the Polish publication Blok (Block), the poet Ion Vinea remarked: “C'est un mouvement d'histoire que cette réalisation d'une internationale intellectuelle par les revues d'avantgarde" ("Carți și reviste") 'It is a historical movement, this creation of an International of Intellectuals through the magazines of the avant-gardes.' ${ }^{3}$ In

1 “Atelierul Revistei 'Integral.'” The journal bears a double inscription on its frontispiece: “Revistă de sinteză modernă. Organ al mişcării moderne din țară şi din străinătate" 'Review of modern synthesis. Organ of the modern movement at home and abroad.' The publication listed editorial offices in both Bucharest and Paris, the latter operated by B. Fondane and Mattis Teutsch. Starting with issue no. 8 from November 1926, Mattis Teutsch, having returned from Paris, joined the Bucharest office. In Paris his place was taken by Ilarie Voronca. Also starting with issue no. 8 an "editor for Italy" by the name of Mihail Cosma (Claude Sernet) began appearing in the list of the editorial staff.

2 The title $u n u$ consistently appeared in all lower-case letters; however, in the following we will follow standard capitalization conventions.

3 Italics mine. 
the same article the phrase, no less totalizing in nature, "art continental unifié" 'unified continental art' appeared. This idea sprang up everywhere, as shown in the examples brought forth by the Romanian avant-garde magazines, which relayed the words of their foreign correspondents. For example, Contimporanul no. 66 (1926) reproduced the call for the creation of a confederation of the literary and artistic avant-garde magazines put forth by Vouloir ${ }^{4}$ a journal from Lille. The collaborators of Vouloir (Want/Will), Theo Varlet, Baudoin, Félix del Marle, Émile Donce-Brisy, and Violaine, wanted to develop a new aesthetic consciousness by proposing principles of a universal style that would lead to the advent of a new art of living. Then, in the June 1925 issue, Integral reprinted the letter originally published in the weekly magazine 7 arts from Brussels addressed to the "Revues et aux Personnalités d'avant-garde" 'Reviews and Personalities of the avantgarde,' which proposed "une réunion des bonnes volontés modernistes" 'a gathering of modernist good will' in the form of an Association Moderniste Internationale (AMI) (International Modernist Association). In the course of the Exposition internationale des arts décoratifs et industriels modernes in Paris, April-October 1925, the immediate objective of AMI was to provide a platform for criticism regarding the choices made by the organizers of the Paris event: " . . affirmer les qualités des essais audacieux représentés à Paris et indiquer nettement les initiatives modernistes sacrifiées par le[s] commissariats nationaux ou auxquelles les circonstances n'ont pas permis de se manifester ([1']Allemagne)"' ... to affirm the qualities of the audacious attempts represented here in Paris, and clearly indicate the modernist initiatives that were sacrificed by the national committees or those whose participation was prevented by circumstances (Germany).' The long-term goals for AMI were exchanges and common action that would ensure being in touch as well as a better representation on the international scene: “Organiser l'[é]change de documents qui permettent aux critiques de définir à chaque moment la situation exacte des efforts nationaux. Des expositions itinérantes ou des éditions communes ne devraient-elles pas être envisagées?" ("Notițe" (Integral 4)) 'To organize the exchange of documents that would allow critics to accurately gauge at all times the status of each national effort. Should we not also envision traveling exhibitions or collective publications?' Integral published a French response on the same page, as part of its unwavering adherence to the Brussels publication's propositions, all the more so as it considered itself threatened "par le mauvais vouloir officiel et public" 'by official and public ill will.' The Romanian artists and poets surrounding Integral defended

4 The magazine Vouloir, led by Émile Donce-Brisy and edited by Charles Rochat, first issued in January 1924, would reach 26 issues by 1927, assembling articles by avant-garde artists such as Mondrian, Van Doesburg, Vantongerloo, Kupka and others, and publishing reproductions of their most remarkable works, as well as those of Huszar, Vantongerloo, Oud, Lissitsky, etc. 
the internationalization of artistic tendencies conveyed by the new currents and called for an opening up of all cultures:

Il est vrai qu'il faudra encore du temps jusqu'à l'unanime compréhension des courants activistes modernes; pour cela, il faudrait supprimer le préjugé séculaire d'un art enfermé exclusivement entre les frontières d'une nation, il faudrait proclamer sans cesse l'idéologie de la vie dynamique, cette remplaçante des vieilles hérésies de caste et de famille; en un mot il faudrait ouvrir pour tous la "boîte à nouveautés" retenue jusqu'à présent à la frontière par les douaniers de la tradition. ("Notiţe" (Integral 5))

It is true that more time is needed to reach a unanimous comprehension of modern activist currents; for this, we would have to do away with the centuries-old bias toward an art exclusively enclosed within each nation's borders, and we would have to incessantly proclaim an ideology of dynamic life replacing the old heresies of caste and family; in short, we would have to open up for all the treasure chest of new ideas until now stopped at the borders by the guardians of tradition. ${ }^{5}$

These are just a few examples of the 'spontaneous contagion' exhibited by the avant-gardes, or in the more flowery language of the painter M. H. Maxy, marked by the same lyrical emphasis common to all the Romanian participants in the avant-gardes, "isbucnirea vie condensată a unui popor europenesc" ("Politica plastică") 'the live condensed eruption of a European spirit.'

\section{Precursors. Alexandru Macedonski and Literatorul. The Spirit of the Modern. A new Aesthetic. Symbolism. Urmuz. The Deconstruction of Language and Literature. The Eruption of the}

\section{Absurd.}

The end of the nineteenth and the beginning of the twentieth century was dominated by the poet Mihai Eminescu (1850-1889). His work was permeated by a Romantic aesthetic: the signified reigned, the poetic discourse relied upon the antithetical, the past was important. With Eminescu, the Romanian poetic language was established. It was now possible to proceed further.

The name of the poet who attempted this feat is Alexandru Macedonski (18541920). A peculiar man, Macedonski boasted baselessly of being the first poet in Europe to have used free verse, which he called "symphonic" or "Wagnerian verse." He managed to patent in France the use of "mother-of-pearl paper," and used colored writing putting into practice, in a typographic sense, both Baudelaire's "Correspondances" and Rimbaud's suggestions of synesthesia in

5 This unsigned article was published as an assessment after the first five issues of Integral. 
"Voyelles." In his literary circle, Macedonski acted like the king of poetry and at the end of an initiatory ritual he offered his disciples (fake) precious stones that he had made himself. The review Literatorul (The Writer) and the homonymous literary circle were joined by a number of poets who would become important figures in modern Romanian poetry.

In Literatorul (published intermittently between 1880 and 1919), and especially in the domain of theory, Macedonski proved to be a formidable innovator. His main subjects were the expansion of the domain of poetry, the complexity of the modern spirit, the value of words in the poetic text, symbolism, and instrumentalism. Following the spirit of the times, he demanded for poetry the right to no longer distinguish between the beautiful and the ugly. According to him, poetry was a chaos of spirit and matter, of cries of distress and mad laughter: “De la sublim la trivial, . . . iată ce trebuie să fie ea!" (64) 'From the sublime to the trivial, . . . that is what [a poem] must be.' The Romanian poet found himself always following in the footsteps of Baudelaire, who had defined the domain of beauty as "the transient, the fleeting, the contingent" 6 and who wrote about the heroism and the beauty of modern life ("De l'héroïsme de la vie moderne" 183).

Alexandru Macedonski wrote several works directly in French: Bronzes (Bucharest: Imprimeria Populară, 1897) and the novel Le Calvaire du feu (Calvary of the Fire) (Paris: Sansot, 1906). This unusual novel, a work of poetic and carnal passion, was the illustration of a double program: an erotic-spiritual initiation on the one hand, and an aesthetic initiation on the other. It is in this second realm in the domain of synesthesia - that the novel was perhaps most successfully experimental: it intended to capture all senses of the reader; each chapter was conceived for the creation of a specific, distinct auditory and color sensation. At the beginning of the twentieth century Macedonski was certainly considered a representative of Romanian modernism, since some of his poems can be found, surprisingly, in Marinetti's 1901 magazine Poesia.

With Macedonski Symbolism had made its entrance into Romanian literature, and it fit better, at least for a while, the expectations of the newer generations of poets. As Fondane wrote in 1922: “Simbolismul a luptat contra imitației după natură, contra copiei, contra prostului-gust, contra familiarității cu viața și cu gustul cititorului - contra cititorului. El a cerut pentru poezie dreptul de-a fi obscură și profundă, de-a fi izolată și particulară, de-a fi prețioasă și ireală dreptul de-a idealiza - excesiv chiar" ("Spre classicismul cel nou" 157) 'Symbolism fought against imitation - of nature or otherwise, against bad taste, against familiarity with life and with the reader's tastes - against the reader. It demanded the right for poetry to be obscure and deep, isolated and unique, precious and

6 "La modernité c'est le transitoire, le fugitif, le contingent, la moitié de l'art, dont l'autre moitié est l'éternel et l'immuable" ("L'Art romantique" 222) 'Modernity is the transient, the fleeting, the contingent; it is one half of art, the other being the eternal and the immovable.' (Selected Writings on Art and Artists 403) 
unreal, the right to idealize, even excessively.' It is easy to understand why in the case of young poets whose formative period coincided with the first two decades of the twentieth century, and who were familiar with French poetry in general and accustomed to reading the French and Belgian symbolist poets, the symbolist aesthetics corresponded best to their need for originality and non-conformism to past values. It was therefore the natural order of things that, when a new group of young men, still high school students in Bucharest, resolving to be innovators and reformers, decided in 1912 to start their own literary magazine, they chose the title Simbolul (The Symbol). These young men were Samuel Rosenstock (the future Tristan Tzara), Eugen Iovanache (the future Ion Vinea) and Marcel Iancu (the future Janco), all around ages sixteen to seventeen. The articles and drawings published on this occasion are not of great interest, but it is the gesture that remains important: they were all in search of a voice and an identity, and were positioned at the start of a process that would only accelerate.

Later, in the course of the full-blown avant-garde adventure, the representatives of this movement would maintain their fondness for certain symbolists, among them Ion Minulescu. ${ }^{7}$ His innovations earned him the admiration of non-conformist young poets, manifested on multiple occasions. A note that appeared in the first issue of Integral salutes his most recent book: " $\mathrm{D}-1$ Minulescu e la noi față de noua generație artistică, ceeace a fost Guillaume Apollinaire față de noua generație franceză" ("Notițe" (Integral 1)) 'Here at home, Mr. Minulescu means for our the new generation of artists what Guillaume Apollinaire meant in France for their new generation of artists.'

Tudor Arghezi ${ }^{8}$ was another much admired "master" for the avant-gardes. It was in his innovative, left-leaning magazine of a diminutive size, but of great notoriety, Bilete de papagal (Parrot Tickets) ${ }^{9}$ that most of the future non-conformist

7 Ion Minulescu (1881-1944, Bucharest), poet, writer, and playwright. After four years spent in Paris, he returned to Bucharest and took the side of the modernists in the debate that pitched them against traditionalists. His 1908 Romanțe pentru mai târziu (Romances for Later Days) was an important event in the history of Romanian literature: it brought innovation in language, irony and self-irony, and freedom in its prosodic structure. In his poetry, Minulescu adopted a repertory of themes and many techniques from Symbolism - repetitions, symmetries, a preference for certain numbers, a penchant for exotic voyages, rare words and rhymes. He also edited journals with symbolist alignments: Revista celorlați (The Journal of Others), 1908, and Insula (The Isle), 1912.

8 Tudor Arghezi (1880-1967, Bucharest) was one of the most important twentieth-century poets. He was also the father of Eli Lotar (1905-1967), a photographer and member of the inner circles of the French avant-garde, a collaborator with Buñuel, and a friend of Alberto Giacometti. Eli Lotar was the director of the 1945 film Aubervilliers, with commentary by Jacques Prévert and music by Joseph Kosma.

9 Bilete de papagal was published, with interruptions, in four distinct series between 1928 and 1945, when it fell under a governmental interdiction and ceased publication entirely. The title alludes to a form of fortune-telling, but "bilete" also means in Romanian "small notes." 
authors were first published. Issue no. 3 of Integral (May 1925) was dedicated entirely to Arghezi's magazine. In paying his homage, Fondane acknowledged Tudor Arghezi's "curative" influence on the younger generation, Arghezi having aided them by his work and his example to rid themselves of "falsul exotism, de falsa literatură, de falsul sentimentalism, de falsul modernism" (Fundoianu, "Omagiu lui Tudor Arghezi" 3) 'false exoticism, false literature, false sentimentalism, false modernism.' Even more enthusiastic, in his impetuous style, Ilarie Voronca found in his elder's poetry certain affinities with avant-garde strategies, going so far to comment, in a remark that would certainly have surprised this exacting master, that Arghezi too was in the embrace of constructivism (under whose banner the editors of Integral rallied at the time). Arghezi's poetic work produced a synthesis between tradition and modernism, while strongly favoring a renewal of poetic language and syntax. But he would not accept this superficial alignment of his work with the aesthetic adventure to which his young admirers subscribed. In a letter to the editor, Arghezi, fearing a hoax perhaps, declared that he was unaffected by any "ideal al ultimului current" (4) 'ideal of the latest current' - which he sought to capture through the ironic story of a car that arrives at its destination before having left.

Let us round out the portrait of the period with the contributions of literary critic Eugen Lovinescu. ${ }^{10}$ The theory of the synchronicity of cultures, to which he subscribed, led him to a position similar to that of the avant-gardes on whose work

10 Eugen Lovinescu (1881-1943, Bucharest), on the basis of the theory of modernism, produced an Istoria civilizației române moderne (History of Modern Romanian Civilisation), 3 vols., 1924-1925, and an Istoria literaturii romane contemporane (History of Contemporary Romanian Literature), 6 vols., 1926-1929. His writings placed literature squarely in the realm of aesthetic autonomy and the perspective he called "the spirit of the century [saeculum]" which plays the role of both starting point and point of convergence for the literary and artistic output of the period, beyond specific differences that did exist. Familiar with contemporary French sociological thinking, especially the work of Gabriel Tarde, he based his theoretical work on the concepts of synchronism, imitation, and mutation of aesthetic values. Lovinescu proved to be in perfect synchronicity with the spirit of the avant-gardes when, in 1925, he formulated an idea that made its way into the thinking of the period: "Spiritul de uniformizare, prin internaționalizarea curentelor, prin fuziunea credințelor și conceptelor ce stau îndărătul oricărei manifestări artistice, progresează atât de mult, încât a făcut pe unii cugetători să prevadă posibilitatea dispariției, prin lipsă de conținut original, a formelor de artă națională" (Istoria civilizației române moderne 388) 'The internationalization of [artistic and philosophical] currents, the fusion of beliefs and concepts upon which all artistic manifestation relies, create to such an extent a spirit of uniformity, that certain thinkers go as far as to predict the virtual disappearance of national forms of art due to the absence of any original content.' Lovinescu reinforces his point, emphasizing precisely how the latest artistic movements were deployed: “. . . în timpurile noastre, impresionismul și cubismul francez, expresionismul german, dadaismul, constructivismul s-au răspândit concentric în toate țările” ‘. . . in our time, French impressionism and cubism, German expressionism, as well dadaism and constructivism spread concentrically into every country.' 
he provided many a favorable commentary. The magazine Sburătorul (1919-1922; 1926-1927) and the literary group bearing the same name, which practically replaced the group led by Macedonski, were the hotbeds of Romanian modernism.

Urmuz (Demetru Demetrescu, Buzău, 1883-1923) was another, perhaps the most spectacular, precursor to the Romanian avant-gardes, but also the most mysterious among them. While his work amounted to only a few dozen pages, the biography of this "personage" had paradoxically aroused the admiration of the young avant-garde artists. Here is the source of the paradox: The life of Urmuz was spent in perfect anonymity; a humble minor official in several towns, he later was the court clerk for the Court of Cassation in Bucharest. At forty, Urmuz shot himself to death, apparently for no reason, other than perhaps anxiety. When he could, he enjoyed playing the piano - and even composing - or just listening to music; this was his great passion in life. He wrote a few small pieces of prose that he liked reading to his family as entertainment.

It is these pieces that earned him posthumous fame and the instant respect of the avant-gardes. In 1928 one publication bore his name (Urmuz, "Magazine of the avant-garde"), reaching five issues between January and July under the direction of Geo Bogza, and in 1930 Saşa Pană, editor of the magazine Unu as well as of the publishing house of the same name, collected the works of Urmuz for the first time in a single volume under the title Algazy $\mathcal{E}$ Grummer. A plethora of articles paid tribute to the work of Urmuz, seen as the agent of both a new sensibility and a new style, and recognizing in their author one of the greatest avant-garde leaders.

In the pieces written before 1910, Urmuz's innovations were the use of the absurd and the image of reified man. His method relied on confusion between the figurative and literal sense of words. To be more exact, the missing figurative level of language creates the aesthetic of reification, this "crisis of reality" of which Fondane would speak later: the evacuation of moral transcendence and the domination of objects can be better rendered by this process. The collage method applied to literary texts also produced surprising effects. Here is the portrait of a character: "Ismail este compus din ochi, favoriți și rochie și se găsește astăzi cu foarte mare greutate. Înainte vreme creștea și în Grădina Botanică, iar mai târziu, grație progresului științei moderne, s-a reușit să se fabrice unul pe cale chimică, prin syntheză." (Urmuz 11) 'Ismaïl is made up of eyes, sideburns, and a dress, and can be found with the greatest difficulty these days. There was a time when Ismail used to grow in the Botanical Gardens as well, but then, more recently, and thanks to the advances of modern science, one has been manufactured chemically through synthesis' (Urmuz 59). In fact, all characters are described in this "mechanomorphic" manner, linking the fictional world of Urmuz with the universe of the visual artists of the time: Picabia, Duchamp, Max Ernst, Victor Brauner, Miró, Dalí, Picasso. This invasion of the object conveys a form of anxiety and engenders an ontologic space in which humans see themselves exiled.

Urmuz's pieces are in defiance of all preceding literature and of a long tradition of literary conventions. The fragment quoted earlier continues: 
Ismail nu umblă niciodată singur. Poate fi găsit însă pe la ora 5 1/2 dimineața, rătăcind în zig-zag pe strada Arionoaiei, însoțit fiind de un viezure de care se află strâns legat cu odgon de vapor și pe care în timpul nopții îl mănâncă crud și viu, după ce mai întâi i-au rupt urechile și a stors pe el puțină lămâie . . . Alți viezuri mai cultivă Ismail în o pepinieră situată în fundul unei gropi din Dobrogea, unde îi întreține până ce au împlinit vârsta de 16 ani și au căpătat forme mai pline, când, la adăpost de orice răspundere penală, îi necinstește rând pe rând și fără pic de mustrare de cuget. (11)

Ismail never walks by himself. He may be sighted about 5:30 in the morning, zig-zagging on Arionoaia Street, in the company of a badger to which he is attached by a steamer cable and which he eats raw after he has ripped off its ears and squeezed some lemon on . . . Ismail raises badgers in a seed-bed in the bottom of a hole in Dobrogea where he keeps them until they are 16 years old and have grown somewhat plump; then, shielded from every kind of penal responsibility, he sets upon dishonoring them, time after time, without the slightest sign of remorse.

Both the sequence of events and the behavior of the characters go against the logic of reality, following instead the strict logic of language. Using normal syntax and logical discourse, Urmuz delves into the absurd and composes a parody of literature. His prose amounts to a negative utopia of language.

Even if in the writings of Urmuz imagery acquires "the highest degree of the arbitrary," as Breton required in his 1924 Manifesto of Surrealism, can we align Urmuz with the surrealists? Eugène Ionesco posed the same question:

Urmuz est-il un authentique surréaliste? Peut-être, comme il n'abandone jamais sa lucidité ironique, est-il seulement un burlesque, frère spirituel de Jarry? Ou encore, si l'on veut y découvrir certaines implications, peutil être considéré comme une sorte de Kafka plus mécanique et grotesque? Les surréalistes de Roumanie le revendiquent comme chef de file. En tout cas, Urmuz est bien . . . un des prophètes de la dislocation des formes sociales, de pensée et de langage dans ce monde qui, aujourd'hui, sous nos yeux se désagrège, absurde comme les héros de notre auteur. (73)

Is Urmuz an authentic surrealist? Perhaps, since he never abandons his ironic lucidity, he is only a burlesque, spiritual brother to Jarry? Or better yet, if we want to discover certain implications in his writings, might we not consider him a more mechanical and more grotesque Kafka? The Romanian surrealists claim him as their leader. At any rate, Urmuz is indeed ... one of the prophets of the dislocation of social forms, of thought and of language in a world that today is disintegrating before our eyes, absurd like the heroes of our author. 
In the absence of any information on Urmuz's readings, we can only speak of coincidences and a meeting of minds, of a spirit that would gradually take over European literature in the twentieth century. For the Romanian avant-garde, finding Urmuz was the equivalent of Lautréamont's rediscovery by the French surrealists.

\section{The messengers. Tzara, Janco, Brancusi, Fondane.}

Several important figures who positioned themselves as "messengers" of the new arts facilitated the development of the avant-garde in Romania. They were Tristan Tzara, Constantin Brancusi, Benjamin Fondane, and Marcel Janco. These artists all had their debut in Romania, then left their homeland at different times and for varying periods - their stay abroad sometimes spanned just a few years, as in the case of Marcel Janco, who returned to Romania after five years (only to leave for Israel permanently twenty years later), but for others the move abroad was definitive, as in the case of Tzara, Brancusi, Fondane, Brauner, and Sernet. And while Brauner managed several exits and returns between Paris and Bucharest from 1925 until 1934, and Brancusi returned multiple times, primarily to show his sculptural ensemble from Târgu-Jiu (The Endless Column and The Table of Silence), others made no significant returns except by way of publishing books in Romanian through their friends: Fondane in 1930 with Privelişti (Views), and Tzara in 1934 with Primele Poeme (First Poems). During the first three decades of the century, from near or afar, directly or indirectly, this group of artists constituted a catalyst for the renewal of the artistic and literary atmosphere of Romania.

They all got their start in the cultural and literary climate of early twentiethcentury Romania, dominated by a confrontation of two models: on the one hand, the traditionalist tendency, as preached by the historian Nicolae Iorga, who founded the magazine Semănătorul (The Sower) and wanted a literature geared toward the enlightenment of the masses and inspired by oral traditions permeated by the orthodoxies of an agricultural people; and on the other hand, modernism, essentially urban, and which found expression in an entirely different language.

B. Fundoianu ${ }^{11}$ from a very early age acquired real fame in Romania, a country that, by ending up on the side of the winners at the conclusion of the war, mended its relationship with History. In his writings from this period, most notably in his book Imagini și cărți din Franța (Images and Books from France), 1921, and in magazine articles published between 1921 and 1922, Fundoianu developed arguments for a firm and definitive adoption of western modernism and wrote about his preoccupation with creating and expressing the times. The twentieth

\footnotetext{
11 Benjamin Wechsler, born in 1898 in Iași, moved to Bucharest in 1919, emigrated to Paris at the end of 1923, and died at Auschwitz in 1944. After becoming known in Romania as B. Fundoianu, he adopted in France the name of Fondane, signing his works from then on as Benjamin Fondane.
} 
century in effect started at the end of the First World War in a series of changes and in the spirit of questioning. The metamorphoses of life, of society, and of the collective psyche, and the renewal of language were the main themes that fed the reflections of the young Fundoianu. After his permanent departure for France, Fondane continued regularly to send poems and, more importantly, reading notes and theoretical articles intended for publication in Romania, most of all in the pages of Integral, 1925-1928, for which he was the editor in France.

In Fondane's view, Dada was positioned at a turning point between cubism, which "ne fut qu'une grande révolution profonde à l'intérieur d'un seul art" 'was but a profound revolution inside a single art form,' and futurism, which proceeded to an updating of spiritual values "par les changements mécaniques du monde contemporain" 'through mechanical changes in the contemporary world' but for which "tout était resté en place" ("Signification de Dada" 32) 'everything stayed the same.' Only Dada, as a movement that rejected all finality and proclaimed the absolute impossibility of creating anything, was found acceptable by Fondane:

Car Dada était la première manifestation connue de l'esprit qui se prétendait catastrophique, qui rejetait toute finalité, qui proclamait le scandale pour le scandale, tout en cachant (ou ignorant peut-être) l'idée obscure qui l'y poussait, qui refusait de se laisser prendre pour un Événement, de se laisser ranger soit dans le fait d'art, soit dans les faits spirituels quelconques, et qui, pour la première fois au monde, refusa "le beau rôle", prétendit vouloir arriver à l'idiotie pure, et déclarait spontanément que le chef-d'œuvre, et même l'œuvre n'était pas possible sur son terrain. (36)

For Dada was the first known manifestation of the mind that pretended to be catastrophic, rejecting all finality, proclaiming scandal for the sake of scandal, hiding (or perhaps ignoring) the obscure idea that drove it, refusing to be considered an Event, to be counted either as art matter or as thought matter, and which for the first time in the world refused "the lead role," claiming instead to pursue pure idiocy, and spontaneously declared that the masterpiece, even the work of art itself, was impossible on its territory.

This was Dada, then, not as an artistic or literary movement, but as a state of mind, a radical insurrection contrarian with respect to the predominance of reason. From the perspective of Fondane's philosophy of existence, Dada constituted an appropriate response, albeit an incomplete and fulgurant one, to the "crisis of reality" which was the symptom of the polymorphous reality of the twentieth century.

Then there was surrealism. As "recherche pure d'une métaphysique de la poésie" ("Les Surréalistes et la révolution" 46) 'pure quest for a metaphysics of poetry', it represented the most advanced artistic tendency in Europe after World War I. Nevertheless, Fondane reproached surrealists for their political stance, 
which for him was incompatible with artistic creation, and for their claim to being "un document mental" (55) 'a mental document" - in other words, for their conceding too important a place in the creative act to the control of reason, or in their words "l'exploitation rationnelle de l'irrationnel" (Faux Traité d'esthétique 54) 'the rational exploitation of the irrational.' Fondane would develop his own thinking on poetry, grounded in a larger philosophical base, through major works published in France: Rimbaud le voyou (Rimbaud the Outcast), 1933, L'Écrivain devant la révolution (The Writer Facing the Revolution), 1935 (published posthumously in 1997), and Faux traité d'esthétique (False Treatise of Aesthetics), 1938. In his own creative work, Fondane experimented with avant-garde aesthetics in cinema alone, first in three film-poems, published in 1928 as Trois scenarii, and then in the much-celebrated Tararira, filmed in Argentina in 1936 and since lost.

In 1913, Tristan Tzara ${ }^{12}$ started writing poems that he intended to be published in Romania by his friend Ion Vinea, at a time when, in the midst of war, Tzara left for Zurich to study in a neutral country. These poems, which occasionally retained the rural flavor of his native world in a fashion similar to Fondane's Privelişti (Landscapes/Views), would be published by Vinea in 1915 in Noua Revistă română (The New Romanian Review) and Chemarea (The Call), then after 1922 in Contimporanul (The Contemporary). They also saw publication as a volume in 1934 in Romanian, and were published in French twice after Tzara's death by Claude Sernet and Serge Fauchereau. ${ }^{13}$ Such publications show an interest in the work of the young poet before his Dada period, but also an attempt to find early signs of Dada, an engagement in a sort of archeology of Dada.

Indeed, these signs do exist, albeit in a discrete form, and quite far removed from the dadaist, bruitist, simultaneist texts proper that would be produced three years later. But what these early texts show is a certain freedom from poetic convention, a replacement of lyricism with humor, irony, anti-lyricism, and antisentimentality. The syntactical relationships are already lax and the poems are composed via juxtapositions, as in this version of "Hamlet" (original title in manuscript), bearing the title "Tristețe cosmică" (Cosmic Sadness) in Saşa Pană's edition, then in Claude Sernet's French translation becoming "Tristesse domestique" ("Domestic Sadness"):

le cheval mange le serpent de la nuit le jardin a mis ses décorations d'empereur robe étoilée de mariée - laisse que je tue ô nuit dans l'infini ta chair fidèle

la folle du village couve des fous pour le palais (CEuvres complètes 1:44)

\footnotetext{
12 Samuel Rosenstock, born in 1896 in Moineşti, Romania, died in 1962 in Paris.

13 See the bibliography at the end of this special issue.
} 
the horse eats the snake of night

the garden has put on its royal robes

the star-studded bridal gown - let

me kill your trusting flesh in infinites, at night

the village madwoman hatches clowns for the palace. (Primele poeme/First Poems 37)

Present in these poems is adolescent playfulness and the enjoyment of rural life (reminiscent of his land of birth), but also a desire and a premonition of departure:

- allons à la fontaine pour que je t'embrasse

- allons au parc communal

jusqu'à ce que le coq chante

pour que la ville se scandalise

- ou au grenier de l'étable pour nous coucher

le foin y pique et l'on entend le ruminement des vaches

ensuite elles ont envie de leurs veaux

partons, partons. ("Le Jour décline"; CEuvres complètes 1: 39)

-let's go to the fountain so I can kiss you

- let's go to the public park

to scandalize the town

until the rooster crows

- or let's bed down in the stable loft

where the hay pricks you and you hear the cows munch

later they pine for their calves

come on, let's go. ("Evening comes"; Primele poeme/First Poems 32)

In the manuscripts of these early poems the reader could already see the poet working out his pseudonym: Tr. Țara, Tristan Țara, and finally Tristan Tzara, the form he would adopt permanently (Litanii avantdada). He left Romania in 1915 and invented Dada in Zurich in 1916 as a remedy against the boredom that his times engendered: “Je n'écris pas par métier et je n'ai pas d'ambitions littéraires. Je serais devenu un aventurier de grande allure, aux gestes fins, si j'avais eu la force physique et la résistance nerveuse de réaliser ce seul exploit: ne pas m'ennuyer" (CEuvres complètes 1:409-10) 'I am not a professional writer and I have no literary ambitions. I should have become a successful adventurer, making subtle gestures, if I had had the physical force and nervous stamina to achieve this one exploit: not to be bored' (Seven Dada Manifestos 87).

The Romanian poets and artists remained in touch with Tzara, as evidenced by the Tzara correspondence located at the Bibliothèque Jacques Doucet in Paris, published by Henri Béhar in the trimestral review Manuscriptum, Bucharest, nos. 2 and 3 from 1982. His correspondents were, at first, Ion Vinea, then Marcel Janco, 
Benjamin Fondane, Ilarie Voronca, Claude Sernet, Jacques Costin, and Saşa Pană. For them, Tzara no doubt embodied a unique international success story, but he remained above all one of them, their spokesperson, the one who planted their flag in Western Europe, indeed on the broader continent itself. And when they started their own avant-garde movements in Romania, with their own magazines and manifestos, they felt they could reuse several concepts of their compatriot, as if they had all drawn inspiration from a common source.

L'artiste nouveau proteste: il ne peint plus (reproduction symbolique et illusionniste) mais crée directement en pierre, bois, fer, étain, des rocs, des organismes locomotives pouvant être tournés de tous les côtés par le vent limpide de la sensation momentanée. ... [L]a réclame et les affaires sont aussi des éléments poétiques. . . . Il nous faut des œuvres fortes, droites, précises et à jamais incomprises. ${ }^{14}$

The new artist protests: he no longer paints (symbolic and illusionistic reproduction) but creates directly in stone, wood, iron, tin, rocks, or locomotive structures capable of being spun in all directions by the limpid wind of the momentary sensation.... [P]ublicity and business are also poetic elements. . . . What we need are strong, straightforward, precise works which will be forever misunderstood. (Seven Dada Manifestos 7-11)

Such wording (Tristan Tzara himself had declared that "Dada belongs to everyone") barely modified or amplified can be found in multiple pieces and manifestos from this period.

Marcel Janco (1895-1984) participated alongside Tzara, Hugo Ball, Emmy Hennings, Jean Arp, and Richard Huelsenbeck in the Dada adventure in Zurich. He furnished illustrations for Tzara's 1916 La Première Aventure céleste de Monsieur Antipyrine (The First Celestial Adventure of Mr. Antipyrine), the first Dada publication, and for the journals Cabaret Voltaire (June 1916) and the first four numbers of Dada (1917-1919), contributing to the creation of a visual identity for the movement via his paintings, engravings, masks, and other objects.

In 1921, Janco followed Tzara to Paris where he met the future surrealists. After a few "querelles dramatiques" 'dramatic arguments' with Tzara and his disenchantment with "les surréalistes en herbe qui n'étaient intéressés que dans la mauvaise plaisanterie et le scandale" 'the surrealists in the making who were not interested in anything other than bad jokes and scandals,' Janco decided to become a "missionnaire de l'art nouveau" 'missionary for the new art' and returned to his

14 Tzara, Dada Manifesto 1918, read on 23 July 1918 in Zur Meise Hall in Zurich, then published in Dada 3, December 1918. CEuvres complètes 1: 362-65. 
native land. ${ }^{15}$ In Romania, Marcel Janco produced a multifarious body of work. He was the cofounder of the first Romanian avant-garde magazine, Contimporanul, in 1922. Between 1924 and the beginning of World War II he organized and participated in group exhibitions. At the same time, he executed several architectural projects that combined creativity and geometrical thinking, while striving for a balance between form and function.

Like other artists of the period, Marcel Janco proved to be a very fine theorist. He wrote theoretical pieces about cubism in aphoristic form (Contimporanul 66, May 1926) and more elaborate articles on architecture. A double issue of Contimporanul (53-54, February 1925) is dedicated to modern architecture. Based on Marcel Janco's initiative, the magazine published extracts from Le Corbusier's Vers une architecture (Toward An Architecture).

Janco was a frequent presence in Contimporanul and other avant-garde publications with his drawings, engravings, and numerous portraits of both French and Romanian authors. As he had done with Dada in Zurich, Janco contributed to the orientation of the Romanian artistic avant-garde in its early stages, where the predominance of constructivism can be noted.

Less direct, but more important, is the influence of Constantin Brancusi (Brâncuși) (1876-1957). Established in Paris in 1904, Brancusi gained international recognition after exhibiting in the 1913 Armory Show in New York. While his approach, in search of archetypal forms, is diametrically opposed to that of the avant-gardes, his contributions, too, became iconic models of modernity. Between 1920 and 1922, Brancusi showed a certain proximity with the Dada group. He befriended Erik Satie, Francis Picabia, Tristan Tzara, and Man Ray and participated in several of the group's activities. Sometime in 1922 he made this note in French on a drawing representing Socrates: "Dada nous amènera les choses à notre temps" 'Dada will bring everything up-to-date.' ${ }^{16}$ Infected with the ludic spirit of his compatriot Tzara, Brancusi himself scribbles a sort of dadaist verse in which "Dada" curiously shifts gender:

Dada est calin

Dada est féroce

Dada est bonne

Dada est méchante

Etc. (Tabart and Lemny 91)

Dada is cuddly

Dada is ferocious

${ }^{15}$ Galerie Denise René, Marcel Janco, n. pag. For further details about the Dada activities in Zurich and the break with the surrealists from Paris, see also Janco, "Janco/Dada."

16 In the Brancusi archives there are several other references in a dadaist style: "Dieu Dada nous apporte la clef du Paradis" (Tabart and Lemny 91) 'God Dada brings us the key to Paradise.' 


\section{Dada is good \\ Dada is nasty \\ Etc.}

On another piece of paper, Brancusi reflects on the phenomenon of Dada, still in French and with the highly idiosyncratic orthography that characterizes his writing in both Romanian and French:

les manifestations dada ne sont que des a[f]fiches

Dada fait pas d'affaires

Dada vous apport[e] de la joie

Dada vous distre [i.e. distrait]

Dada vous d[é]crasse le[s] cerveaux

Dieu Dada vous ap[p]ort[e] la clef du Paradis. (Tabart and Lemny 91)

Dada events are nothing but publicity posters

Dada does not conduct business

Dada brings you joy

Dada entertains you

Dada scours your brain

God Dada brings you the key to Paradise.

But the relationship between Brancusi and the avant-garde as artistic movement did not go any further; he would pursue his own path solitarily.

Yet for several decades Brancusi remained a model and a beacon, and his Paris studio a frequent meeting place for Romanian artists. Tristan Tzara, Ilarie Voronca, and Benjamin Fondane were all frequent visitors, and for a while in 1930 Jacques Hérold even worked in his studio. For his part, Brancusi made sure that his work was known in Romania. Until the start of World War II he regularly participated in the salons of Tinerimea Artistică (Artistic Youth) and in 1924, at the time of the great international exhibition of modern art organized by Contimporanul, Brancusi, whose name carried weight, participated as a Romanian artist.

The Romanian avant-garde as a literary and artistic movement is constituted around several key publications in three distinct periods: 1922-1928, 1928-1939, and 1941-1947.

\section{2-1928. Journals and Manifestos. "Pictopoems." Integralism and Synthesis.}

In June 1922 Ion Vinea and Marcel Janco, old friends and companions of Tzara's in his early adventures, laid the foundation for the longest-lived avant-garde magazine, Contimporanul (reaching 102 issues between June 1922 and January 1932). They published essays and articles on various European movements: constructivism, the Russian avant-garde and the manifesto of the group called 
Serapion Fraternity, the Hungarian avant-garde and the group Ma (Today), and the Polish artistic movement. Many of the theorists and artists of the period published articles in Contimporanul: Hans Richter, Richard Huelsenbeck, Lajos (a.k.a. Ludwig) Kassák, Yvan Goll, Paul Dermée, Georges Linze, Tristan Tzara, and others; among the Romanian authors we find Ion Vinea, Ion Călugăru, I.G. Costin, Ion Barbu, and Ilarie Voronca. The visual contents were provided in large part by the drawings and engravings of the "house artists" Marcel Janco, M.H. Maxy, and Mattis Teutsch, but Contimporanul also published works contributed from abroad, by artists like Fernand Léger, Enrico Prampolini, Juan Gris, and Karel Teige.

In 1924, with issue no. 46, Contimporanul launched the first manifesto of the Romanian avant-garde, titled "Manifest activist către tinerime" (Activist Manifesto for Youth). Between the introductory call, "Jos Arta căci s'a prostituat!" 'Down with Art, because it has prostituted itself!' and the final exclamation "Să ne ucidem morții" ‘Let us kill our dead!' all traditional forms of artistic expression are closely examined: poetry, theater, and the novel, as well as painting, sculpture, and architecture. Music alone was given a break, judging by the surprisingly lyrical tone of the definition it was given amidst the inventory of shortcomings: "Music, a means of locomotion in heaven."

Jos Arta

căci s'a prostituat!

Poezia nu e decât un teasc de stors glanda lacrimală a fetelor de orice vârstă;

Teatrul, o rețetă pentru melancolia negustorilor de conserve;

Literatura, un clistir răsuflat;

Dramaturgia, un borcan de fetuși fardați;

Pictura, un scutec al naturii, întins în saloanele de plasare;

Muzica, un mijloc de locomoțiune în cer;

Sculptura, știința pipăirilor dorsale:

Arhitectura, o antrepriză de mausoleuri înzorzonate;

Politica, îndeletnicirea cioclilor si a samsarilor

. . . Luna, o fereastră de bordel la care bat întreținuții banalului și poposesc plăpânzii din furgoanele artei. ("Manifest activist către tinerime" 10)

Down with Art, because it has prostituted itself!

Poetry is a mere press, good for pressing the lachrymal glands of girls of all ages;

Theater, a recipe for melancholy for the sellers of cans;

Literature, a stale enema;

Drama, a potful of painted fetuses;

Painting, nature's diaper, hung in the salons of investment;

Music, a means of locomotion in heaven;

Sculpture, the science of fondling from behind; 
Architecture, an enterprise for decked out mausoleums;

Politics, the business of undertakers and usurers;

... the Moon, a brothel window on which the procurers of banality are

knocking, while the feeble are halting the cartfuls of art.

Similar to other programmatic texts, this manifesto did not stop at proclaiming decrepitude as the basic state of traditional art, but it also preached the features of new art being created, which had to fit the rhythms of the industrial era. Theater would abandon, like an old skin, anecdote and sentimentality, "clișeiele șterse ale vieții burgheze" and "obsesia înțelesurilor și a orientărilor" 'the clichés of bourgeois life' and 'the obsession with meaning and orientation'17 in favor of authentic life. The novel would give way to reportage, and style would adopt the "plastic, precise, and rapid" expression of "Morse machines." The poets and the artists would exult at the sight of great urban crowds, of inorganic environments, and, well before the appearance of major cities and great industries in their country, they would indulge in machinist dreams.

Nevertheless, it is surprising to see in this first avant-garde manifesto a list of requirements almost classical in nature, in which the elements of balance and the simplification of artistic methods predominate: "Vrem . . . simplificarea procedeelor până la economia formelor primitive (toate artele populare, olăria și țesăturile românești, etc.)." ("Manifest activist către tinerime” 10) ‘We want ... the simplification of methods to the point of the economy seen in primitive art (all popular art, Romanian pottery and textiles, etc.).' In 1922 Fondane believed that poetry was heading "toward a new classicism," whose roots would feed from Symbolism, just as Mihail Cosma (Claude Sernet) did, concluding a programmatic article about integral art with the words: "Cu pași giganți și siguri, ne îndreptam către o incandescentă epocă de clasicizat" (9) 'with giant and firm stride, we direct ourselves toward an incandescent age of classicism.' They expressed this need, so characteristic of the difficult beginnings of the early twentieth century, to find a point of equilibrium for "the metaphysical despair" of mankind. This quest became permanent and fed on itself; paradoxically it led to the tendency of the twentieth century to make permanent, even systematize, anxiety, neurosis, and ecstasy, as well as the unconscious, desire, and the irrational. The different movements of the avant-garde are the best illustration of this point. Between cubism and futurism, Dada, constructivism, and surrealism, there is more continuity and equivalency than rupture - if we look beyond the "power struggles" and the personal conflicts between individuals.

\footnotetext{
17 The word "orientation" is used here in the sense of "directed thought" referring to the way poetry had functioned for centuries and which Tristan Tzara, taking inspiration from C. G. Jung, wanted to replace by "non-directed" or magical thought, which is created via images. For more detail, see Tzara, "Essai sur la situation de la poésie" (1930; CEuvres complètes 5:7-28).
} 
The question was not posed in "Manifest activist către tinerime," nor would it be throughout the history of the Romanian avant-garde up to the beginning of the Bucharest surrealist group, whether to institute or to recreate in pure form this or that "ism": dadaism, futurism, constructivism all ran alongside each other, mixing and coexisting. They wholly shared the desire to change art, change literature, destroy old conventions, and shock the reader.

"Manifest activist către tinerime" had the role of releasing a giant mass of energy that had been compressed and waiting for the first sign to erupt: several magazines calling themselves "modern" or "avant-garde" or "of international constructivist art" or "of modern synthesis" saw publication, took over from or succeeded one another for a long decade. $75 \mathrm{HP}$, issued in a single number in October 1924, would be succeeded immediately by Punct, with sixteen issues between November 1924 and March 1925; then Integral took over between March 1925 and April 1928, only to pass the baton on to Unu, which saw fifty issues between March 1928 and June 1932. There were also numerous books, pamphlets, posters, exhibitions, events, games, and farces.

$75 \mathrm{HP}$ was the most radical publication of the time, also the most spectacular with its typographical audacity and graphic presence, well ahead of its time and not just in Romania. 75 HP declared itself "l'unique groupe d'avant-garde de Roumanie" 'the only avant-garde group from Romania.' Its members presented themselves, writing in French, in a manner reminiscent of Dada:

LE GROUPE 75 HP organise un grand thé[â]tre anti-thé[â]tral avec des repr[é]sentations foudres asphaltes hépatisme diat[h]ermie acide carbonique LES SPECTATEURS DOIVENT VENIR EN TOILETTES SP[É]CIALES PR[É]VUS de gants de boxe de chaussures de pommes de terre de [k]laxons trompettes signaux de revolvers préférables browning des perruques d'asbeste. (75 HP 1: n. pag.)

THE GROUP 75 HP organizes an anti-theatrical grand theater with thunder asphalt shows hepatitis diathermy carbonic acid THE AUDIENCE MUST COME DRESSED IN SPECIAL CLOTHES EQUIPPED with boxing gloves with potato shoes with car horns bugles revolvers preferably Brownings asbestos wigs.

Here, too, is the list of qualities required in those who wish to publish in the new magazine - again in French:

POUR COLLABORER À 75 HP il faut :

savoir bien danser

uriner sur tout

respecter ses parents

avoir souffert un

accident d'avion

ne pas faire de la 


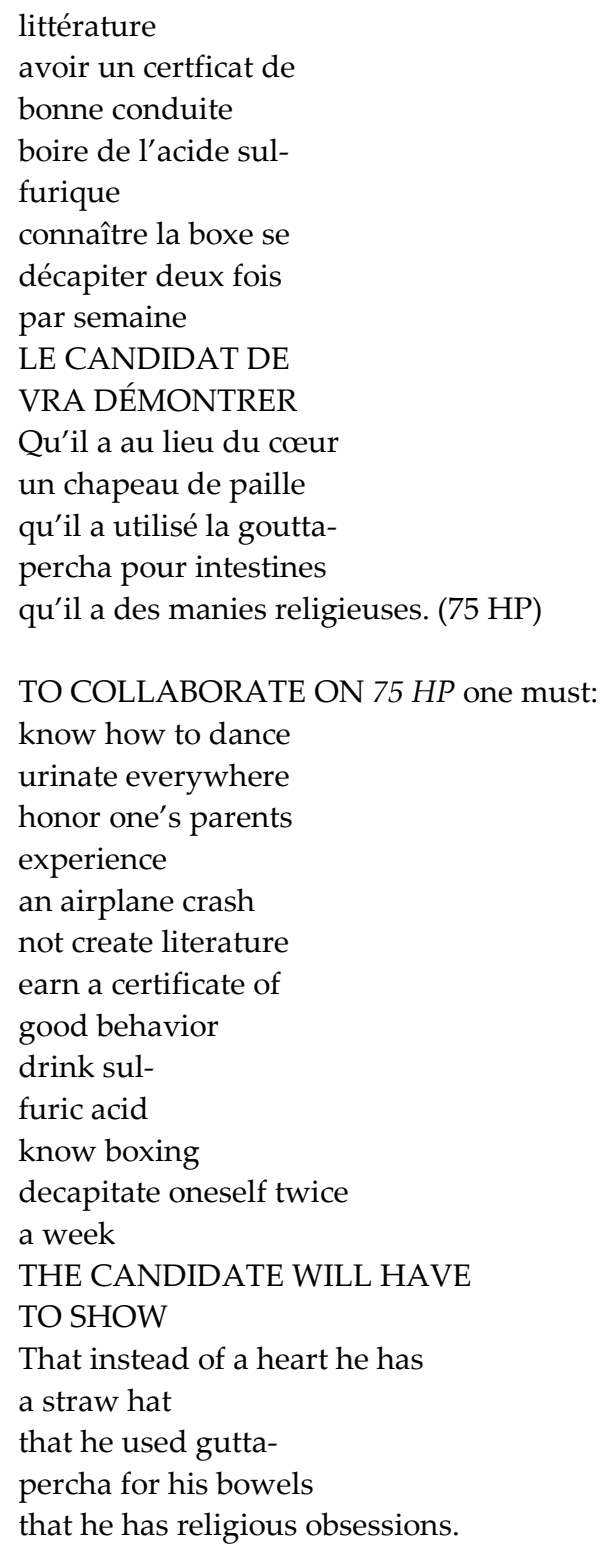

This unsigned introductory text as well as the manifesto "Aviograma" signed by Ilarie Voronca both reveal a desire to sever ties with literary traditions. "Do not create literature," one of the requirements listed in the manifesto of $75 \mathrm{HP}$, followed in the footsteps of Tristan Tzara's Dada manifestos and also coincided with one of the defining elements of surrealism as presented by Breton in his first Manifeste du surréalisme, "en dehors de toute préoccupation esthétique" (CEuvres complètes 1: 328) 'exempt from any aesthetic . . . concern' ("Manifesto of 
Surrealism" 26). The call by Voronca takes a much more radical tone on a later page in $75 \mathrm{HP}$ in the form of a scatological sentence by Mihail Cosma (Claude Sernet): “'LITTÉRATURE' LE MEILLEUR PAPIER HYGIÉNIQUE DU SIÈCLE” ‘ “LITERATURE” THE BEST TOILET PAPER OF THE CENTURY.'

Two other theoretical articles by Voronca, "1924" and "Victor Brauner," eulogize modern art and adopt the tone and program set by the Manifesto in Contimporanul. The article on Brauner especially establishes several important points. The new art, Voronca proclaims, has broken with sentimentalism and no longer deals with aesthetic pleasure. Art is no longer tributary to sensibility or feelings, but to "capacității cerebrale" 'the cerebral capacity.' The abolition of mimesis is also evoked: "Artistul însă e înainte de toate inventator" 'But the artist, before anything else, is an inventor.' Voronca, the poet, imagines a new ontological status for artistic creation: "Insist: ceea ce revine artei și în cea mai înaltă manifestare a ei, este lărgirea cunoștințelor noastre abstracte, crearea unor noi raporturi de înțelegere, mărirea razei asociațiunilor de idei” (“Victor Brauner") 'I insist: what belongs to art, in its highest manifestation, is the expansion of our abstract awareness, the creation of novel relationships of understanding, the amplifying of the associative network of ideas' ("Victor Brauner" [translation] 534). Voronca's article on Brauner also focuses on a specific characteristic of the avant-gardes seldom discussed theoretically-the idea of the unattained, the incomplete: "Era desăvârșirilor e sfârșită. Acum a sunat ceasul tuturor încercărilor îndrăznețe fie chiar cele mai absurde" 'The age of refinement has come to an end. Now chimes the clock of every audacious attempt, even the most absurd.' The works of the avant-garde artists were unfinished works, works in progress that were being created under the eyes of the spectator/reader - this conception applied equally as well to simultaneist poetry and to Tzara's performances in Zurich, not to mention the surrealist productions.

After a few general points, Voronca comes to the main topic of his article: Victor Brauner. Once again, the poet's intuitions, if we consider these from the perspective of the painter's later evolution, have proved to be on the mark. For Voronca, Victor Brauner belongs to a special breed of prolific innovators in art. Abstraction, unique composition, and the unusual are the artist's strengths. Rejection of sentimentality and logic results from an uncommon suprasensory ability. The subsequent evolution of the painter is already drawn in surprisingly precise ways in Voronca's essay. An important note: Alain Jouffroy, in his 1959 monograph on Brauner, mentions Ilarie Voronca as one of the painter's most decisive contacts in his earliest artistic period. ${ }^{18}$

18 “L'amitié de Voronca et de Brauner fut sans doute plus initiatique qu'il ne leur semblait. Ils projetaient l'un dans l'autre leurs plus secrètes, leurs plus intimes visions. L'ineffable fit partie de leur jeu concret. La Pictopoésie définit ce pacte spirituel que tout grand peintre scelle avec le poète. Leur communauté de vision fait naître un monde” (Jouffroy 26) ‘The friendship 
The main founding members and editors of 75 HP, Ilarie Voronca and Victor Brauner, introduced here their recent invention, "pictopoetry," as "la vraie synthèse des futurismes dadaïsmes constructivismes" "the true synthesis of futurist, dada, and constructivist tendencies.' This new genre was, incidentally, one of the most important contributions of the Romanian avant-garde. Pictopoetry is not the same as either the poem-collage as practiced by Paul Éluard and Max Ernst in Répétitions and Malheurs des immortels, both from 1922, or Magritte's use of words in his "tableaux-pièges" 'trap pictures' (like the well-known phrase "Ceci n'est pas une pipe" 'This is not a pipe' in The Treachery of Images). In "pictopoetry" words are integrated into the image structure, on the same level as paint or color, and are at the same time both signifiers and purely visual elements. This new genre embodied a very clear desire to find trans-language support for a type of work that explored the "suprarational" - according to a formula expressed in a mix of French and Romanian, "RÉPERTOIRE ABSTRAIT SUPRARATIONAL" "ABSTRACT SUPRARATIONAL REPERTORY." This notion, which appeared for the first time in the pages of $75 \mathrm{HP},{ }^{19}$ is close to the idea of "surrationalism" (or "rationalisme dialectique") introduced in the epistemology of Gaston Bachelard in his essay "Le Surrationalisme." It is only dream, like a syphilis of the unconscious, that colors the soul with the foam of a spiritual pustule.' The dream, this "permanentă efervescență a neprevăzutului" 'permanent effervescence of the unforeseen' is not the opposite of reality, but an intensification of it, its realization: "Vreau visul voiaj fantastic în subconștient, vreau visul sondă, visul solid, visul sinucidere" 'I want the fantastic voyage dream into the unconscious, I want the probe dream, the solid dream, the suicidal dream.' Geo Bogza pushed even further his lyrical hypotheses, which took on the appearance of a well-controlled delirium, musing on the first suicide and the first madman in the history of mankind. And if "the first man" were also the first dreamer, he wondered, could we not assume that he would perceive dreams to be reality? At this stage, Bogza's surrealism was "empirical," but his reflection laid down its premises and pushed to the extreme the possible consequences of the relationship between dreams and diurnal life. The same territory of dreams would be claimed by Gherasim Luca and his friends as "initiates" (in surrealism, naturally, but also in Freud and other authors who had tackled dreams), having internalized Bogza's experience before denying, according to the rules of an implacable dialectic, all earlier contributions on the subject.

between Voronca and Brauner no doubt was closer to an initiation than either of them realized. They each projected onto the other their innermost secrets and most intimate visions. The ineffable was part of their concrete game. Pictopoetry defines the type of spiritual pact that is struck between any great painter and the poet. Their shared vision brings forth the world.'

19 "The same year (1924) when the word "surrealism" appeared officially, Brauner, in Romania, employed the concept of "surrationalism" for the first time in the magazine $75 \mathrm{HP}$, which he had founded in Bucharest with Voronca" (Clébert 549). 
The most important surrealist work of the Unu period was the magazine itself, an archetypal collective creation that bears witness to a veritable innovative effervescence and an authentic liberty of spirit. The avant-garde movements created a trend for the collective "work" by relativizing the meaning of the term through extension or complicit and ironic attribution, be it in pamphlets, manifestos, farces, or events. The different groups created a common stock of words, concepts, and methods from which everyone drew as if in a sort of mutual benefit society, similar to the "société anonyme pour l'exploitation du vocabulaire" 'corporation for the exploitation of the vocabulary' imagined by Tzara. For this reason, the authorship of certain texts is often interchangeable, proof of a perfect symbiosis between contributors. The collective texts of the Romanian surrealist group, founded later by Gherasim Luca and Gellu Naum, are the "site," the only site, where five protagonists found themselves effectively in such unison that their voices fuse into one.

The magazine Unu was, for four whole years, the crucible of an exuberant creativity and the privileged site of an exemplary communion, infusing a sense of gravity into the group members' insatiable appetite for play: "Toți pentru unu și unu pentru toți" 'All for one [unu] and one for all.' Let us note, in the same vein, the family business of Stephan Roll's father, a creamery that Victor Brauner called "Secolul" 'The Century,' no doubt ironically, but also as a humorous reference, via the familiar Romanian expression "a-şi face veacul" ("veacul" and "secolul" both meaning "the century"), to the idea of frequent and lengthy visits to a place. The shop was dominated by the image of a cow painted on the window which, due to an intervention by Victor Brauner, acquired the status of a work-of-art, although alas an emphemeral one. ${ }^{20}$ Despite its "rustic" smells, the creamery was the lively gathering place of the very urbane avant-garde artists during the years of Unu, serving as needed as an editorial office, a meeting place, a "literary salon," as well as an observatory of social reality.

In 1931, Saşa Pană, the editor-in-chief, under pressure from Stephan Roll, who had become more and more engaged in the ideology of the Communist Party, whose activities were carried out illegally at the time, decided to break with surrealism and to radicalize the magazine's political orientation. The two components of surrealism, the aesthetic and the ideological, were incompatible in their view. As his correspondence from these years demonstrates, Stephan Roll, like any "soldier" loyal to the party, had been contaminated by the idea of total and uncompromising adherence, having rejected as "reactionary" all forms of

20 "In acea zi, care era și ultima zi a secolului, m-am fotografiat cu Roll afară (prin antifrază "la borcan"), sprijiniți de vitrina cu vaca pictată cu mâna și corectată la uger de Victor Brauner" (Născut în '02 355) 'That day [26 October 1931] which was the last day of the Century, I had my photo taken outside (as opposed to "in the acquarium") with Roll, leaning against the store window with the hand-painted cow whose udder had been somewhat modified by Victor Brauner.' 
personal freedom, free thinking being one the most dangerous among them ("Stéphane Roll à Benjamin Fondane"). Without much conviction Sașa Pană followed him, and this decision, not by any means unanimously accepted by the group, would accelerate their disbanding and the cessation of the periodical in December 1932.

Subsequent to Unu, special mention ought to be made of Viața imediată 'Immediate Life'21 as well as its manifesto, "Poezia pe care vrem să o facem" (The Poetry We Want To Make). Published on the first page, this collective manifesto (signed by Geo Bogza, Gherasim Luca, Paul Păun, and S. Perahim) marked a rupture with the preceding avant-garde movement. The signatories reproach their precursors and contemporaries, whom they call "cavalerii modernismului hermetic" 'the knights of hermetic modernism' for having reduced poetry to the simply technical. Lautréamont ("la poésie sera faite par tous, non par un" "poetry will be made by all, not by one') and Breton ("la beauté convulsive" 'convulsive beauty' ${ }^{22}$ ) are present in the text via allusions to well-known phrases barely modified: "vrem să facem o poezie pentru toți oamenii, pentru miile de oameni" 'we want to make poetry for all people, for thousands of people' and "frumusețea violentă și încă nescrisă a epocii actuale" 'the violent and as yet undescribed beauty of these times.' But the authors of the manifesto set aside the artistic or "cultural" aspects, favoring an "estetica elementară a vieții" 'elementary aesthetics of life.' Poetry was to accompany man on his existential adventure, to regain his vigor and return to the source: life itself. At this same time, Luca and Păun were the first in Romania to introduce, in the leftist press, "proletarian poetry."

In the individual works of the Unu period, each artist followed, in a more or less established style, the process of the renewal of language and artistic means by employing - with varying intensity - certain surrealist themes, or at least verbal "tics."

The lyricism of Ilarie Voronca ${ }^{23}$ (1903, Brăila - 1946, Paris) is of the kind where exuberance comes from an uncanny ability to create memorable images. The poet's wonderment at the world gives particular freshness to the poems written in

${ }^{21}$ Bucharest, December 1933 (single issue). Editor, Geo Bogza.

22 The concept revealed to Breton at the close of Nadja, 1928, which he later developed in L'Amour fou, in 1937.

${ }_{23}$ Poetry volumes published: Restriști (Sadness), with drawings by Victor Brauner (Bucharest, 1923); Colomba, with two portraits by Robert Delaunay, the drawing on the cover by Sonia Delaunay (Paris, 1927) ; Ulise (Ulysses), with a portrait by Marc Chagall (Paris, Coll. Integral, 1929); Brățara nopților (The Nights' Bracelet), with a drawing by Victor Brauner (Bucharest, 1929); Zodiac, with a drawing by M.H. Maxy (Bucharest, Ed. unu, 1930); Invitație la bal (Invitation to the Ball) (Bucharest; Ed. Unu, 1931); Incantații (Incantations), with a portrait by Milița Petrașcu (Bucharest, 1931); Petre Schlemihl, illustrations by Michonze, Brauner, and Perahim (Bucharest, 1932); Patmos și alte șase poeme (Patmos and Six Other Poems) (Bucharest, 1933). In 1933 he settled in France, and continued to write and publish in French. 
Romania: his texts capture the ring of happiness. Neither the resolutely and exclusively modern lexicon, nor the abandonment of syntax which provides the required speed of communication but also leads to the cold regularity of well-oiled mechanisms - none of these deprive Voronca's texts of their singular lyrical tone.

Stephan Roll24 (pseudonym of Gheorghe Dinu; 1903, Florina, Greece - 1974, Bucharest), divided between his "alimentary" work in his father's small creamery and the modern man he wanted to be, an archetypal urbanite and lover of sports, judging by his theoretical writings in Integral, cultivated an immoderate taste for wordplay. His predilection for this type of exercise would however not go beyond a certain form of self-satisfaction and self-celebration of the virtues of language. His semantic ambiguities, despite their undeniable spontaneity and freshness, remain only modestly revealing, menaced by their own mechanics, all too visible. The poet Stephan Roll gave way progressively to the militant communist Gheorghe Dinu, his real name, in whose eyes poetic subversion and revolutionary action were not equivalent.

Between Roll and Voronca was Sașa Pană (1902, Bucharest-1981, Bucharest), whose originality consisted in his enthusiasm for Unu (the group and the journal) and the friendships both entailed. He was the unifier of the group, and later he would become its devoted chronicler. ${ }^{25}$ Let us also note the prose writings of Jacques Costin ${ }^{26}$ (1985, Bucharest - 1972, Paris), Ion Călugăru ${ }^{27}$ (1902-1956), or Moldov ${ }^{28}$ (pseudonym of Marcu Taingiu, 1907, Dorohoi - 1966, Baltimore), all of whom wrote in a style half-way between Urmuz and automatic writing.

The most passionate and in his quest the most radical and feverish among these writers was Geo Bogza (1908, Ploiești - 1993, Bucharest), most notably in his Jurnal de sex (Sex Journal), 1929, and above all in Poemul invectivă (Invective Poem), 1933. The latter was published with the author's fingerprints, an act through which he symbolically delivered himself to justice, having already been found culpable of "outrage against public morals" but also a friendly reference to his young

\footnotetext{
24 Notable publications: Poeme în aer liber (Open Air Poems) (Bucharest: Integral, 1929); Moartea vie a Eleonorei (The Living Death of Eleanor) (Bucharest: Editura Unu, 1934).

${ }^{25}$ His Născut în '02 (Born in '02) is an extraordinary source of information about the atmosphere surrounding the artistic avant-garde in Romania during the period 1924-1944. Sașa Pană published both poetry and prose, and he was the editor of the Romanian poems of Tristan Tzara as well as of the writings of Urmuz (Urmuz, Ed. Unu, 1930, second edition in 1933 under the title Algazy \& Grummer).

${ }^{26}$ Exerciții pentru mâna dreaptă şi Don Quichotte (Excercises for the Right Hand and Don Quixot), with drawings by Marcel Janco and Milița Petrașcu (Bucharest, 1931).

27 Paradisul statistic (Statistical Paradise) (Bucharest, 1926); Abecedar de povestiri populare (Primer of Folk Tales) (Bucharest: Ed. Unu, 1930).
}

${ }_{28}$ Repertoriu (Répertoire) (Bucharest: Ed. Unu, 1935). 
friends at Alge, who had used this type of signature in their journal. ${ }^{29}$ The two collections show us Bogza battling with the need to express his wanderings in the realm of desire and an explosive sexuality, the chief means through which he expressed his social revolt. In Poemul invectivă it is with a kind of jubilant audacity fed both by a desire to subvert and the pleasure to provoke that the poet inventories ". . . aceste flori monstruoase ale sexualității / Aceste tentative superbe de dragoste și moarte" ("Poemul efebilor predestinați" 24) '. . . these monstrous flowers of sexuality / These superb attempts at love and death," which he lists all throughout the chapter in the category of taboos and prohibitions: incest in all its manifestations, zoophilia, fetishism, voyeurism, the "open air" masturbation of the shepherd in the Carpathians ("Unde ciobanul întâlnit se masturba în aer liber / Și câinii de la stână lingeau pe piatră sperma" ("Esseu" 39) "Where the encountered shepherd was masturbating in the open air / and the sheepdogs were licking the sperm on the stone'), prostitution and joyous debauchery, homosexual prostitution among thieves in a prison. Each text is a transgression, and liberated pleasure is not of the realm of libido, but of pure rebellion. The expression is hard, brutal, percussive, without however going into the nether areas of the lexicon; the unspeakable is spoken with verve for atonement. Not only do the forms of forbidden love-making to which Bogza is referring bring love and death together, but the poet is exposing himself to extreme danger, drawing from this act his great, his well-earned voluptuous pleasure:

Ar trebui un imn pentru căldură, un altul pentru alunecare

Numai în căldura suavă a dormitoarelor materne

Pot naște aceste flori monstruoase ale sexualității

Aceste tentative superbe de dragoste și moarte

Când mâna alunecă pînă la șold pe pulpa goală a mamelor tinere

Și prin ferestre răsună pocnetul de armă al tatălui întors în clipa tragică a ejaculării. (“Poemul efebilor predestinați" 24)

We need a hymn for heat, another for sliding

Only in the suave warmth of maternal bedrooms

Can these monstrous flowers of sexuality be born

These superb attempts at love and death

When the hand slides to the hip on the naked thigh of young mothers And through the windows resounds the gunshot of the father returning in the tragic moment of ejaculation.

\footnotetext{
29 Editors' note: Alge (Algae) was a youthful and provocative journal of the early 1930s, founded by Aurel Baranga. The members of the eponymous group of contributors to the journal are sometimes referred to as algişti. For further information, see in this volume the poem "Strigăt."
} 
This type of experience constituted no doubt one of the lasting influences on the young Ghérasim Luca, first visible in his works between 1930 and 1933.

The expansion of literary periodicals had a match in the realm of the visual arts. Let us note the year 1924 when the first personal exhibition of Victor Brauner opened on 26 October, followed in November by the international exhibition organized by Contimporanul. The latter brought together all the important European avant-garde artists of the period who were accessible to the organizers: Hans Arp, Paul Klee, Hans Richter, and Kurt Schwitters, from Germany; Marc Darimont and Marcel Lempereur-Haut from Belgium; Lajos Kassák from Hungary; Mieczysław Szczuka, from Poland; the Swedish Viking Eggeling; the Czech Karel Teige; and finally the Romanians: Constantin Brancusi, Marcel Iancu, Milița Petrașcu, M.H. Maxy, Mattis Teutsch, and Victor Brauner, "un très jeune mais très vigoureux talent qui malgré ses intentions encore inavouées dans la peinture réussit à capter notre intérêt par une très belle œuvre graphique" (“L'Exposition Internationale du 'Contimporanul' ") 'a very strong, talented young artist who, although he hasn't yet revealed his intentions as to painting, managed to captivate our interest with his very beautiful graphic work.' Over the course of the years, Contimporanul would organize other exhibitions which, while not quite on the international scale of the first one, would maintain - along with other manifestations, as for example the annual salon titled Tinerimea artistică (The Artistic Youth) - the public interest in various forms of modern art and certainly a familiarity with them. This would later on make possible the reception of the most radical works of Victor Brauner, the bold pieces of young Perahim, or Trost's colored graphies, indecipherable mancies, and vaporizations, Păun's infrablack drawings, and Gherasim Luca's cubomanias and objects.

\section{0-1947. The Romanian Surrealist Group, or Life in Life}

In 1940, Gellu Naum (1914, Bucharest-2001, Bucharest) and Gherasim Luca (1913, Bucharest-1994, Paris) started a surrealist group in Bucharest. They had just returned to Romania after a two-year stay in Paris where their friend Victor Brauner had introduced them to the circle of André Breton. The artists invited into the group were Paul Păun (1915, Bucharest-1994, Haifa), Virgil Teodorescu (1909, Cobadin-1987, Bucharest), and D[olfi] Trost (1916, Brăila-1966, Chicago?). With the exception of Trost, who had not previously published literary works, each had already published books or collaborated in the various avant-garde journals. They were also communists, either party members or sympathizers, and active in the leftist press. Beyond aesthetic, philosophical, and plastic affinities with, and in the case of some of them, a veritable vocation for surrealism, in the selection of new members the two co-founders established an indispensable requirement of 
"ideological purity that fits in with the theses and manifestos of André Breton." 30 Breton had come closer to the theories of Trotsky, with whom during the summer of 1938 in Mexico he had launched the call for the creation of a Fédération internationale de l'art révolutionnaire independent, F.I.A.R.I. (International Federation of Independent Revolutionary Art), where 'independence' meant freedom from any form of ideological pressure originating with either of the two main totalitarian regimes of the time, fascist and Stalinist: "Toute tendance progressive en art est flétrie par le fascisme comme une dégénérescence. Toute création libre est déclarée fasciste par les stalinistes" 'Every progressive trend in art is branded by fascism as degenerate. Every free creation is labeled fascist by the Stalinists.' ${ }^{31}$ A few months later, the day before the Munich Agreement, with a lucidity for which he was known and which does not cease to surprise even today, in Ni de votre Guerre ni de votre paix (None of Your War Nor Your Peace!), Breton denounced the looming war as a consequence of the guilty complicity between the Second and Third International and capitalism. In September 1938, from Paris, Luca apparently sent this pamphlet to Bucharest, thus attracting the condemnation of the Romanian Communist Party, as well as the label Trotskyite, a synonym of 'traitor' in the hierarchy of deviations as defined by the Party. ${ }^{32}$ In these conditions, the Breton-Trotsky option was the "ideological purity" required from the adherents of the Romanian surrealist group, the acceptance of which at the end of 1940 and all through the long years of the war would have put them in a doubly subversive position: first as opposed to the main political order established in Romania, dominated by a nationalist right that was viscerally anti-Communist, thus anti-Soviet; but also as opposed to the Communist Party which, as a mere section of the Third International, had to submit to the orders arriving from Moscow, where Trotsky was considered a criminal traitor, having in fact been eliminated, in August 1940, by the inescapable "long arm of the Revolution."

The subversion of subversion - this could define the nature of such an option. In 1940 this exaltation of subversion became the rallying cry of the new group being formed, and furnished it with a founding principle, a program, and a code of conduct. In Gellu Naum's account, the ideological exigency would have made ineligible several potential members, such as Isidore Isou and Paul Celan (Laville

\footnotetext{
30 This according to the reminiscences of Gellu Naum, source of this succinct history of the group, for which see Laville 50. For other perspectives on the group, see Paul Paon's 1977 and 1993 interviews mentioned in the introduction to Yaari, ed., "Infra-noir," un et multiple (p. 8, n. 20), which also provides a general overview.

31 André Breton and Léon Trotsky, "Pour un Art révolutionnaire indépendant" (CEuvres complètes 3: 690); "Manifesto for an Independent Revolutionary Art" (Free Rein 34). When this manifesto was first published in 1938, the name of Diego Rivera appeared instead of Trotsky's to protect the latter from Soviet prosecution.

32 This episode, related by Naum to Laville, is supposed to have provoked Luca's exclusion from the party, which is hard to verify. See Laville 50; compare with Tănase 49.
} 
50-51); in any case, they were not residing in Bucharest during the time of the group's activity through the war years, and they left Romania for France immediately or soon after the end of the war. The significant absence of Perahimwhose work as a painter and earlier participation alongside the "algişti" (members of the Alge group) Luca and Păun had earned him the status of one of the beacons of Romanian surrealism - was also due to the Trotskyite "lens" as well as to his actual exile in the Soviet Union during the war.

By the beginning of the year 1941 the program of the Romanian surrealist group is fully constituted and can be synthesized in these terms: rehabilitate dreams, giving them the status of objective reality; erase their latent content, which is but a simplified summary of "the Oedipus complex," in favor of their manifest content; give full consideration to desires, which are considered a kind of code for the human personality. Poetry for them was a way of being and, implicitly, a way of knowing, the only one capable of rebuilding the unity of the world and the unity of being. Dreams and wakefulness, chance, mediums, sleepwalking, encounters, and apparitions were all put to use.

But the world was at war. Romania joined the Axis powers, an act followed by a number of laws which, added to those already in place, aggravated and intensified their effect: there were severe limitations of freedom and a hardening of the legal provisions against Jewish citizens. The surrealist group, with three Jewish and five former or current leftist militant members, reduced by the long absences of Gellu Naum, who had been mobilized and sent to the front, found itself pushed into a clandestine, secret existence: there were no public events, no pamphlets, no publications, nothing to signal or legitimize such a movement. Deprived of all exchanges with others outside the group and of any immediate relationship with the social, political, artistic, philosophical surroundings, the Romanian surrealists were forced to turn exclusively inward. Cut off from the world, wrapped in a bubble of silence, they lived "the eruption of dreams into the diurnal" as well as other surrealist incursions into the quotidian. The five poets came to surrealism with such despair, such anger, such a delirious passion that they would never be able to say that surrealism was a stage, a phase, an experience, a parenthesis, something on the order of ephemera like an illness that has aftereffects, but of which one is cured. Romanian surrealism was resolutely experimental and this reality of "lived experience" was undoubtedly its strongest characteristic.

On the level of the "daily experience" the group as such was marked by several setbacks - ruptures, scissions, quarrels - that could not all be ascribed to the hostility of history. Nevertheless, a certain number of shared ideas, obsessions, constructions and syntagms present in their respective writings give the Romanian group an identity within international surrealism and proves the existence of a real complicity among its members.

It also means that the Romanian surrealists were from the beginning engaged in a sort of race to exceed the objectives of surrealism as understood and 
proclaimed by Breton just a few years later, in 1947 to be more exact, at the time of the opening of the grand post-war international exhibition in Paris.

In some way, the members of the Romanian surrealist group knew how to take advantage of their late arrival onto the international scene - a delay that had no other reason but that of historical circumstances - by borrowing from surrealism and developing its most audacious conquests. Proof of this was the falsely naïve pleasure, full of self-irony but above all enthusiasm, to have brought into the surrealist terminology the type of neologistic superlatives that communicated their desire of surpassing or exceeding what was already in place: (causal) surdetermination, surdeterminism, surautomatism, surthaumaturgy.

At the end of the war, the climate in Bucharest had all the appearance of freedom regained. Alas, this state would prove not just illusory, but also partial and temporary. It was sufficient, however, to allow the group to shed its silence. The exhibitions organized as early as January 1945 and the books and manifestos published in quick succession between 1945 and 1947 constitute the main body of Romanian surrealism, where collective thinking, discoveries, and even illuminations coexisted with individual particularities. All their output was edited under the mantle of publishing houses or collections whose names, in French or Romanian, were conceived as emblems of the group: Colecția suprarealistă with a French variant, Collection surréaliste, Éditions de l'Oubli (Oblivion Editions), Editura Negația-Negației (Negation of Negation Editions), Infra-noir (Infra-black), and S Surréalisme.

During this period members of the group were also reestablishing contact with the outside world. Their hopes and thoughts were directed toward friends in Paris, Victor Brauner and Jacques Hérold, but also toward André Breton and Sarane Alexandrian, the latter, from 1947, secretary of "Cause," the international secretariat of the surrealist movement (Alexandrian, L'Évolution de Ghérasim Luca à Paris). The pamphlet Dialectique de la dialectique: Message adressé au surréalisme international ("Dialectics of the Dialectic") marks the desire of Romanian surrealists to signal their existence and to highlight their original contributions. Written directly in French, it is both a signal of distress, providing "comme dans les grands naufrages" 'as with major shipwrecks,' the planetary coordinates of the group ("à $44^{\circ} 5^{\prime}$ de latitude nord et $26^{\circ}$ de longitude est" (n. pag.) ' $44^{\circ} 5^{\prime}$ latitude north and $26^{\circ}$ longitude east' ("Dialectics of the Dialectic" 32)), as well as a concise but complete and very Cartesian presentation of their theoretical and practical propositions. And while the text was conceived and written by Luca and Trost, in the historiography of the movement it remained an overall representative document of the Romanian surrealist group considered as a whole ${ }^{33}$.

Love, the eroticization of the proletariat, and the concept of the "non-oedipal" formed the principal axis of theoretical reflection, the objective of which was to

33 Editors' note: For a closer look at this question of representativity, see the articles in this volume by Hansen, Toma, and Yaari. 
align interior and exterior reality. Love was declared to be "notre principale méthode de connaissance et d'action" 'our principal means of knowledge and of action.' Freed from any kind of constraints, it also became "la méthode révolutionnaire relative-absolue" 'the relative-absolute revolutionary method.' As a result, "l'érotisation sans limites du prolétariat" 'the unlimited eroticisation of the proletariat' was a means to ensure for the latter "un réel développement révolutionnaire" (Dialectique de la dialectique 18-19) 'a real revolutionary development" ("Dialectics of the Dialectic 37). ${ }^{34}$ The problem of total liberation of man, which was the focus of the international surrealist movement's quest since its first manifesto, found a possible solution in the non-oedipal position Luca elaborated (in Inventatorul iubirii (The Inventor of Love)) ${ }^{35}$ and which supported his own onto-poetic program. The rejection of the "dialectique encerclée de la nature œdipienne, mélancolique et persécutrice" (Amphitrite 2) 'dialectic encircled by an Oedipal, melancholy, and persecutory nature' and its replacement with a nonOedipal position would result in a new approach to dreams and thus to both consciousness and the unconscious. The Romanian surrealists recognized "l'identité du fonctionnement réel de la pensée à travers la vie diurne, la folie et les rêves" 'the identity of the real functioning of thought through diurnal life, madness, and dreams' without distinction, and they declared that they were in search of understanding the oneiric in the diurnal state, thus drawing close to achieving "la confusion complète de l'existence diurne et de l'existence nocturne, par la négation de leur séparation artificielle. .. . " (Dialectique de la dialectique 2627) '[the] total fusion of diurnal and nocturnal existence, through the negation of their artificial separation. ...'

In the domain of the visual arts, to which they referred with the phrase "knowledge via the image," Luca and Trost made a distinction between "les images produites par des moyens artistiques et les images dues à des procédés scientifiques, strictement appliqués, tels que l'action du hasard et de l'automatisme" 'images produced by artistic means and the images resulting from rigorously applied scientific procedures, such as the operation of chance or of automatism.' They pleaded in favor of 'l'emploi absurde des procédés aplastiques, objectifs et entièrement non-artistiques" (Dialectique de la dialectique 26-27) 'the absurd use of aplastic, objective, and entirely non-artistic procedures.'

\footnotetext{
34 As poetically extravagant as it may seem, this idea of the Romanian surrealists has a precedent in the initiative of Wilhelm Reich (1897-1957), disciple of Freud, who in 1931 in Berlin founded the Sexpol, an "association pour une politique sexuelle prolétarienne" 'association for a proletarian sexual politics,' whose agenda stressed the cause to effect relation between capitalism and sexual répression.' See Elchaninoff 50.

35 Gherasim Luca, Inventatorul iubirii urmat de Parcurg imposibilul și de Moartea moartă (Bucharest: Editura Negația Negației, 1945). Cf. Luca's own French translation: L'Inventeur de l'amour suivi de La Mort morte (Paris: José Corti, 1994); English transl. by Julian and Laura Semilian: The Inventor of Love and Other Writings (Boston: Black Widow P, 2009).
} 
After this they turned to the procedures they themselves were putting forward: the object objectively offered, entoptic graphomania, vaporization, hypnagogic movements ("tableaux peints les yeux fermés" 'paintings made with closed eyes'), the object-analysis ("interprétation de quelques objets dans un état léger de somnambulisme provoqués par eux" 'interpretation of objects in a state of light sleepwalking provoked by these objects'), echography, stereotypy, pantography, cubomania. All of these methods are based on automatism pushed "jusqu'à ses limites les plus concrètes et absurdes (le surautomatisme, le talisman-simulacre), objectivisant d'une manière ininterrompue le hasard et l'obligeant à renoncer à son caractère de rareté. ..." (Dialectique de la dialectique 27-28) 'to its most concrete and absurd limits (sur-automatism, talisman-simulacrum), objectivizing chance in an uninterrupted fashion thus forcing it to become less rare. ...'

In a handwritten document sent to Breton with a copy of his 1946 book, Connaissance des temps, Trost painted a fuller picture of the direction and activities of the group. Here is the first paragraph, under the side heading "Dans l'ordre général":

Travaux théoriques et expérimentaux sur l'amour, considéré comme la principale force révolutionnaire, croyance en la toute-puissance de la poésie, préoccupation d'inventer de nouveaux désirs non-liés au passé infantile, négation de toute activité politique ou de collaboration avec les éléments non-surréalistes, tendance à s'organiser en centre secret, de type initiatique, refus de considérer la réalité de l'obstacle extérieur, la femme vue en tant que moyen de transmuer le monde, développement des états somnambuliques, par artifices poétiques, pour provoquer la rencontre, sur une même sphère du conscient et de l'inconscient, négation de l'inconscient œdipien, développement du délire d'interprétation en tant que voie ouverte au hasard favorable. Tendance à concilier l'amour unique avec l'amour multiple, éternité de tout amour. Études sur l'hystérie d'après des documents peu connus. Affirmation de la vie dans la vie comme lieu idéal de la rencontre, accent sur le noir, le nocturne, le mal. Satanisme poétisé. Études sur la médiumnité, expérimentales, aussi. Tendance à unifier les participants dans un groupe absolument homogène, collectif jusqu'à l'identification. Acceptation intégrale de toutes les thèses surréalistes connues jusqu'au début de la guerre. Travaux sur le rêve, comme choix de rêves uniquement pour leur beauté poétique dans leur contenu manifeste ou bien rêves provoqués dans des conditions établies d'avance. Recherche d'une nova capable de donner la réponse aux interrogations surréalistes récentes. ("Activité du groupe surréaliste de Bucarest (1940-1950)")

Theoretical and experimental work on love, considered the principal revolutionary force, belief in the all-powerfulness of poetry, preoccupation with inventing new desires unrelated to the infantile past, negation of all political activity or collaboration with non-surrealist elements, tendency to function as a secret center of the initiatory type, refusal to consider the reality of external the obstacle, woman seen as a means to transmute the world, development of sleepwalking states by poetic artifices, in order to provoke the encounter, on the 
common plane of the conscious and the unconscious, negation of the Oedipal subconscious, development of the delirium of interpretation as an open path to favorable chance. Tendency to reconcile the unique love with multiple loves, eternity of love. Studies of hysteria based on little-known documents. Affirmation of life in life as an ideal site of encounter, emphasis on the black, the nocturnal, the evil. Poeticized Satanism. Studies on mediums, also experimental. Tendency to unify the participants in an absolutely homogenous group, collective to the point of identification. Complete acceptance of all surrealist theses known until the outbreak of the war. Work on dreams, either a choice of dreams based only on their unique poetic beauty in their manifest content or dreams provoked in preestablished conditions. Search for a nova capable of providing answers to the latest surrealist interrogations.

The group, at times divided, at others united, continued its activities until the publication of the last two collective works in 1947, Éloge de Malombra: Cerne de l'amour absolu (In Praise of Malombra: Shadow of Absolute Love) (Bucharest: S Surréalisme) and "Le Sable nocturne" (Nocturnal Sand), the latter written for and published in the exhibition catalogue of Le Surréalisme en 1947, which was the first major event of international surrealism after the war, taking place in July at the Galerie Maeght in Paris. ${ }^{36}$ In "Devant le rideau" (Before the Curtain), the opening text of the catalogue, André Breton addresses an important signal to "nos amis de Bucarest" 'our friends in Bucharest,' recognizing their place at the forefront of the search for new paths within Surrealism: "Selon l'heureuse formule de nos amis de Bucarest, 'la connaissance par la méconnaissance' demeure le grand mot d'ordre surréaliste" ("Devant le rideau," 1947; CEuvres complètes 3: 744) 'In accordance with the formula coined by our friends in Bucharest, "knowing through unknowing" remains the principal surrealist motto.' In this phrase, taken from "Le Sable nocturne," Breton must have found a confirmation of his own concern with taking surrealism, by surpassing its previous stage, into the realm of a new myth. ${ }^{37}$ Breton's remark is the equivalent of "homologating" the Bucharest group, but, through one the ironies of history, at the very moment of the group's dissolution.

In 1947, then, the "shipwreck" that Luca and Trost had signaled two years earlier in their joint "message addressed to international surrealism" referring to their situation at the end of the war, came to pass in a different way, now that Romania was being brought to enter the orbit of the Soviet Union for the long term.

36 Editors' note: The group had published only one other text signed by all five of its members, accompanying Gherasim Luca's, Trost's, and Păun's joint exhibition of 1946: L'Infranoir. Préliminaires à une intervention sur-thaumaturgique dans la conquête du désirable. Additionally, all but Gellu Naum published two plaquettes in the arguably "collective" series [Collection Surréaliste] Infra-noir (1947).

37 The letter of invitation to all participants in the exhibition indeed expressed a desire and intention to mark a certain progress relative to the earlier activities of surrealism as a whole (Breton, “Comète surréaliste," 1947. CEuvres complètes 3: 757). 
The surrealist group was dissolved and its members dispersed "to the four winds:" Ghérasim Luca went to France in the early fifties, where, after having left surrealist orthodoxy behind, he continued to write poetry dedicated to "the poetic questioning of the sign" (Carlat 263); Paul Păun left for Israel a decade later, where he continued writing and drawing; Trost, after a short stay and two volumes published in France, chose to live in the United States ${ }^{38}$; Virgil Teodorescu became a protégé of the Communist Party and entered the Romanian Academy; finally, Gellu Naum led a very discrete life in Romania, in accordance as a matter of fact with his own nature and predisposition for "le rêve diurne" 'diurnal dreaming." While the work of Luca, Păun, and Trost fell into an "orchestrated" neglect-the type that the Communist regime reserved to all those who had chosen to escape to freedom beyond the "iron curtain" - Gellu Naum enjoyed success in Romania's literary circles, starting from the 1970s until his death in 2001, earning a quasiunanimous recognition.

Apart from other unique characteristics in the context of international surrealism, a key trait of the Romanian surrealist group is their bilingualism. The use of French both in order to stay connected to French surrealism and the international movement it generated, and to stake a position uniquely their own, was the necessary condition for their existence as a distinct group. They were not wrong in this, because it is their French publications, above all the collective pamphlets and manifestos of the full group, that have consistently served as basis of reference to the group's activities in the histories and syntheses dedicated to international surrealism. In a well-documented and subtly argued study, when analyzing the motivations behind the use of French by Romanian surrealists, Monique Yaari proposes the adoption of the terms "Surrealist Group of Bucharest" and "of French expression" rather than "Romanian Surrealist Group" (103). ${ }^{39}$ And yet, the texts written in French collectively or individually and published in Romania during the years 1945-1947 belong to a corpus of Romanian surrealist works. Furthermore, the scope and importance of the surrealist writings in Romanian by Gherasim Luca, Gellu Naum, Paul Păun, and Virgil Teodorescu ${ }^{40}$ provide solid and credible support for another possible term, "the Romanian surrealist group."

Translated from the French by Irma Giannetti

\footnotetext{
${ }^{38}$ Editors' note: With respect to the lesser known trajectories of Trost and Păun, see the "Introduction" and the chapters dedicated to each of them in Yaari, "Infra-noir," as well as, in this volume, articles focused on their work.

39 Cf. Yaari 101-04 and 132-34 to follow the full extent of her argumentation. In a later work, she proposed the denomination 'Infra-noir' group."

40 Trost published no surrealist texts in Romanian, but he participated in a collective text as yet unpublished.
} 


\section{Works Cited}

75 HP. 1924. Reprint ed. Marina Vanci-Perahim. Paris: Place, 1993. N. pag. Print. “Academia Artelor Decorative." Integral 9 (Dec. 1926): 2. Print.

Alexandrian, Sarane. L'Évolution de Ghérasim Luca à Paris (Evoluţia lui Ghérasim Luca la Paris). Ed. and trans. Nicolae Tzone, Ioan Prigoreanu, and Marilena Munteanu. Bucharest: Vinea, 2006. Print.

Arghezi, Tudor. “Ce trebuie să ştie un tânăr la 45 de ani." Integral 5 (July 1925): 4. Print.

“Atelierul Revistei ‘Integral'” (advertising insert). Integral 1 (1 March 1925): 2. Print.

Bachelard, Gaston. "Le Surrationalisme." Inquisitions 1 (1936). 1-6. Print.

Baudelaire, Charles. L'Art romantique. 1846. Paris: Nouvelle Revue française, 1923. Print. CEuvres complètes de Charles Baudelaire 4. Print.

- . "De 1'Héroïsme de la vie moderne." 1846. CEuvres complètes de Charles Baudelaire. Ed. F.-F. Gautier. Paris: Nouvelle Revue française, 1925. 183-87. Print.

- Selected Writings on Art and Artists. Trans. P. E. Charvet. Harmondsworth: Penguin, 1972. Print.

Bogza, Geo. "Eseu.” 1933. Poemul invectivă: Cu amprentele digitale ale autorului. Ed. Nicolae Tzone. Bucharest: Vinea, 2009. 38-39. Print.

—. "Poemul efebilor predestinați." 1933. Poemul invectivă: Cu amprentele digitale ale autorului. Ed. Nicolae Tzone. Bucharest: Vinea, 2009. 22-24. Print. —. "Reabilitarea visului." Unu 34 (March 1931): n. pag. Print.

Bonnet, Marguerite. “D'une 'Préface' à un 'Manifeste.' CEuvres complètes. By André Breton. Ed. Marguerite Bonnet. Paris: Gallimard, 1988-2008. 1: 133238. Print.

Braudel, Fernand. Grammaire des civilisations. Paris: Flammarion, 1993. Print.

Breton, André. "Crisis of the object." Surrealism and Painting. Trans. Simon Watson Taylor. Boston: MFA, 2002. 275-80. Print.

- Free Rein. Trans. Michel Parmentier and Jacqueline d'Amboise. Lincoln: U of Nebraska P, 1996. Print. French Modernist Library.

- "Manifesto of Surrealism." Manifestoes of Surrealism. Trans. Richard Seaver and Helen R. Lane. Ann Arbor: U of Michigan P, 1969. 1-47. Print.

—. CEuvres complètes. Ed. Marguerite Bonnet. Paris: Gallimard, 1988-2008. 4 v. Print. Bibliothèque de la Pléiade.

Carlat, Dominique. Ghérasim Luca l'intempestif. Paris: Corti, 1998. Print.

"Carți și reviste." Contimporanul 49 (Nov. 1924): n. pag. Print.

Clébert, Jean-Paul. Dictionnaire du surréalisme. Paris: Seuil, 1996. Print.

Cosma, Mihail. “De la futurism la integralism." Integral 6-7 (October 1925): 8-9. Print. 
Elchaninoff, Michel. "Berlin, 1931, Wilhelm Reich: Les Masses libidineuses." Philosophie magazine 67 (March 2013) : 50-51. Print.

“L'Exposition Internationale du 'Contimporanul.'” Contimporanul 52 (Jan. 1925): n. pag. Print.

Fondane, Benjamin. Faux traité d'esthétique: Essai sur la crise de réalité. 1938. Ed. Ann Van Sevenant. Paris: Paris-Méditerranée, 1998. Print.

—. "Signification de Dada." Le Voyageur n'a pas fini de voyager. Ed. Patrice Beray and Michel Carassou. Paris: Paris-Méditerranée, 1996. Print.

- "Les Surréalistes et la révolution." Integral 12 (April 1927). Rpt.: Fundoianu/Fondane et l'avant-garde. Ed. Petre Raileanu and Michel Carassou. Paris: Paris-Méditerranée, 1999. 46-52. Print.

—. Trois scenarii: Ciné-poèmes de Benjamin Fondane. Brussels: Documents internationaux de l'esprit nouveau, 1928. Print.

Fundoianu , B. “Note dintr-un sertar.” Imagini si cărți. Ed. Vasile Teodorescu. Bucharest: Minerva, 1980. 423-25. Print.

—. "Omagiu lui Tudor Arghezi." Integral 3 (May 1925): 2-3. Print. "Spre classicismul cel nou." Imagini si cărți. Ed. Vasile Teodorescu. Bucharest: Minerva, 1980. 154-58. Print.

“Frigidaire." Unu 16 (Aug. 1929): n. pag. Print.

Galerie Denise René. Marcel Janco. Paris: Galerie Denise René, 1963. Print.

Ghérasim Luca. Amphitrite: Mouvements sur-thaumaturgiques et non-oedipiennes. Bucharest: n.p., 1947. Print. Infra-noir.

Ghérasim Luca and Trost. "Dialectics of the Dialectic." Surrealism Against the Current: Tracts and Declarations. Ed. and trans. Michael Richardson and Krzysztof Fijałkowski. London: Pluto P, 2001. 32-41. Print.

—. Dialectique de la dialectique: Message adressé au mouvement surréaliste international. Bucharest: 'S' Surréalisme, 1945. Print.

Ionesco, Eugène. "Précurseurs roumains du surréalisme: Urmuz." Les Lettres Nouvelles N.S. 13 (1965): 71-73. Print.

Janco, Marcel. “Janco/Dada: An Interview with Marcel Janco." By Francis M. Naumann. Arts Magazine 57.3 (Nov. 1982): 80-86. Print.

Jouffroy, Alain. Victor Brauner. Paris: Fall, 1996. Print.

Kroha, Jiř́. Sociologický fragment bydlení. 1934. Brno: Krajské stredisko státní památkové péče a ochrany prírody, 1973. Print.

Laville, Rémy. Gellu Naum: Poète roumain prisonnier au château des aveugles. Paris: Harmattan, 1994. Print.

Lovinescu, Eugen. Istoria civilizației române moderne. 1924-25. Ed. Z. Ornea. Bucharest: Editura Științifică, 1972. Print.

Macedonski, Alexandru. “Despre poemă.” 1881. Opere. Ed. Mircea Coloșenco. Vol. 3. Bucharest: Fundației Naționale pentru Știință și Artă, 2007. 60-72. Print.

"Manifest activist către tinerime." Contimporanul 46 (16 May 1924): 10. Print.

Maxy, M. H. “Politica plastică." Integral 9 (Dec. 1926): 3. Print. 
"Notițe." Integral 1 (1 March 1925): 15-16. Print.

“Notițe." Integral 4 (June 1925): 14. Print.

“Notițe." Integral 5 (July 1925): 14. Print.

Pană, Sașa. Născut în '02: Memorii - file de jurnal - evocări. Bucharest: Minerva, 1973. Print.

"Precizări." Integral 5 (July 1925): 2-3. Print.

Roll, Stéphane. "Stéphane Roll à Benjamin Fondane: Bucarest, le 8 mars 1943." Fundoianu/Fondane et l'avant-garde. Paris: Paris-Méditerranée, 1999. 112-17. Print.

Tabart, Mareille, and Doïna Lemny, eds. La Dation Brancusi: Dessins et archives. Paris: Centre Pompidou, 2003. Print.

Tănase, Stelian, ed. Avangarda românească în arhivele Siguranței. Iași: Polirom, 2008. Print.

Trost. "Activité du groupe surréaliste de Bucarest (1940-1950)." André Breton, 42 rue Fontaine. Vol. [2], Livres II. Paris: Calmels Cohen, 2003. 284. Print.

Tzara, Tristan. Litanii avantdada. Ed. Alexandru Condeescu. Bucharest: Muzeul Literaturii Române, 1996. Print.

- "Marchez au pas: Tristan Tzara parle à Integral." By Ilarie Voronca. Integral 12 (April 1927): 6-7. Print.

—. CEuvres complètes. Ed. Henri Béhar. 6 vols. Paris: Flammarion, 1975-1991. Print.

- Primele poeme/First Poems. Trans. Michael Impey and Brian Swann. New York: New Rivers P, 1976. Print.

- Seven Dada Manifestos and Lampisteries. Trans. Barbara Wright. London: Calder; New York: Riverrun P. 1981. Print.

Urmuz. "Ismaiil şi Turnavitu (Ismail and Turnavitu)." Trans. Stavros Deligiorgis.

Urmuz. Ed. Stavros Deligiorgis. Bucharest: Cartea Românească, 2001. 11-13

(Romanian), 59-61 (English). Print.

Vinea, Ion. "Principii pentru timpul nou." Contimporanul 61 (October 1925): n. pag. Print.

Voronca, Ilarie. “Aviograma.” 75 HP 1 (Oct. 1924). Print.

. "Aviogramă." Trans. Monica Voilescu. Between Worlds: A Sourcebook of Central European Avant-gardes, 1910-1930. Ed. Timothy O. Benson and Éva Forgács. Los Angeles: Los Angeles County Museum of Art; Cambridge: MIT Press, 2002. 535-37. Print.

—. "Glasuri." Punct 8 (9 Jan. 1925): n. pag. Print.

—. "Suprarealism și integralism." Integral 1 (March 1925): 4-5. Print.

—. "Victor Brauner." 75 HP 1 (Oct. 1924). Print.

. "Victor Brauner." Trans. Julian Semilian and Sanda Agalidi. Between Worlds: A Sourcebook of Central European Avant-gardes, 1910-1930. Ed. Timothy O. Benson and Éva Forgács. Los Angeles: Los Angeles County Museum of Art; Cambridge: MIT Press, 2002. 534-35. Print. 
Yaari, Monique, ed. "Infra-noir", un et multiple: un groupe surréaliste entre Paris et Bucarest. Oxford: Peter Lang, 2014.

Yaari, Monique. "The Surrealist Group of Bucharest: Collective Works, 19451947." Paris-Bucharest, Bucharest-Paris: Francophone writers from Romania. Ed. Anne Quinney. Amsterdam: Rodopi, 2012. 95-136. Print.

Copyright (C) 2015 Petre Răileanu 